\title{
An integrated risk assessment and management framework for carbon capture and storage: a Canadian perspective
}

\author{
Patricia Larkin* and William Leiss \\ McLaughlin Centre for Population Health Risk Assessment, \\ University of Ottawa, \\ Room 216A, 600 Peter Morand Crescent, \\ Ottawa, K1G 5Z3, Ontario, Canada \\ Email: plarkin@xplornet.com \\ Email: leissw@queensu.ca \\ *Corresponding author \\ Joseph Arvai \\ Ross School of Business, \\ University of Michigan, \\ 701 Tappan Street, Ann Arbor, MI 48109, USA \\ Email: jlarvai@umich.edu
}

\section{Maurice Dusseault}

Department of Earth and Environmental Sciences, University of Waterloo, 200 University Avenue West, EIT-2043, Waterloo, N2L 3G1, Ontario, Canada

Email: mauriced@uwaterloo.ca

\section{Mamadou Fall}

Faculty of Engineering, University of Ottawa, CBY A016, 161 Louis Pasteur, Ottawa, K1N 6N5, Ontario, Canada Email: mamadou.fall@uottawa.ca

\section{Robert Gracie}

Department of Civil and Environmental Engineering, University of Waterloo, 200 University Avenue West, Room E2-2321, Waterloo, N2L 3G1, Ontario, Canada Email: rgracie@uwaterloo.ca 


\section{Anthony Heyes}

Department of Economics, University of Ottawa, 120 University (9029), Ottawa,

K1N 6N5, Ontario, Canada

Email: anthony.heyes@uottawa.ca

\section{Daniel Krewski}

McLaughlin Centre for Population Health Risk Assessment, University of Ottawa,

Room 216A, 600 Peter Morand Crescent, Ottawa, K1G 5Z3, Ontario, Canada

Email: dkrewski@uottawa.ca

Abstract: This concluding paper of the Special Issue on carbon capture and storage (CCS) in the Canadian context provides a brief overview of the findings from all contributions, followed by a description of the Canadian policy and regulatory backdrop for CCS at both the federal and provincial levels in active jurisdictions. An integrated risk management framework (IRMF) is proposed with reference to environmental and human health risk assessment and risk management frameworks published worldwide as well as risk management demonstrated in large scale Canadian CCS projects to date. Key features of the IRMF are the ten-step rational and transparent process, options to engage with and integrate wide-ranging government and non-government stakeholders on an ongoing basis, and incorporation of independent external review. The next generation of risk-based decision making is then applied to the IRMF for CCS.

Keywords: carbon capture and storage; risk assessment; risk management; Canada; framework; health; environment; injection; storage; policy context.

Reference to this paper should be made as follows: Larkin, P., Leiss, W., Arvai, J., Dusseault, M., Fall, M., Gracie, R., Heyes, A. and Krewski, D. (2019) 'An integrated risk assessment and management framework for carbon capture and storage: a Canadian perspective', Int. J. Risk Assessment and Management, Vol. 22, Nos. 3/4, pp.464-508.

Biographical notes: Patricia Larkin is a Post-Doctoral Fellow. Her field of research, population health, considers structural and intermediary determinants of health and their interactions, with a goal to protect or improve human health. With a focus on applied risk management, she is undertaking research, writing and project management at the McLaughlin Centre for Population Health Risk Assessment and the Institute for Science Society and Policy. She is an active member of the Society for Risk Analysis. She holds her Master in Geography and Graduate Diploma in Population Health Risk Assessment and Management.

William Leiss is a Fellow and Past-President (1999-2001) of the Royal Society of Canada and an Officer in the Order of Canada. He is currently a scientist at the McLaughlin Centre for Population Health Risk Assessment, University of Ottawa. From 1999 to 2004, he held the NSERC/SSHRC/Industry Research Chair in Risk Communication and Public Policy at the Haskayne School of Business, University of Calgary. From 1994 to 1999, he held the Eco-Research 
Chair in Environmental Policy at Queen's University (Ontario). He is the author of Risk and Responsibility (1994), Mad Cows and Mother's Milk: The Perils of Poor Risk Communication (1997, 2004); in the Chamber of Risks: Understanding Risk Controversies (2001), all from McGill-Queen's University Press.

Joseph Arvai is the Max McGraw Professor of Sustainable Enterprise in the School of Natural Resources and Environment and the Ross School of Business, at the University of Michigan. He is also the Director of the Erb Institute for Global Sustainable Enterprise at the U of M. His research is focused on advancing our understanding of how people process information and make decisions, with a specific emphasis on how people make tradeoffs. $\mathrm{He}$ also conducts research focused on developing and testing decision-aiding tools and approaches that can be used by people to improve decision quality across a wide range of environmental, social and economic contexts. His research is applied and accounts for decision-making by a broad spectrum of public and stakeholder groups, as well as by technical experts, business leaders and policy makers.

Maurice Dusseault teaches Geological Engineering and does research in deep underground engineering issues including hydraulic fracturing, energy storage, geothermal energy, mining, carbon sequestration, deep solids and liquids waste disposal through injection and wellbore integrity. He holds over 80 international patents and has about 525 full-text papers published in journals and conferences. He is a well-known educator and advisor, and in the last few years has served as advisor to five different Canadian provinces $(\mathrm{AB}, \mathrm{QC}, \mathrm{NB}$, $\mathrm{NS}, \mathrm{NL}$ ) on matters relating to energy development, hydraulic fracturing, energy geostorage, wellbore integrity, technology and innovation.

Mamadou Fall is a Full Professor in the Department of Civil Engineering at the University of Ottawa (Canada) and the Director of the Ottawa-Carleton Institute for Environmental Engineering. He obtained his $\mathrm{PhD}$ in Geotechnical Engineering from the Freiberg University in Germany. He was the Coordinator of the German Research Chair of Environmental Geosciences and Geotechnics. He has over 15 years' experience on fundamental and applied research on underground disposal and management of wastes (e.g., radioactive wastes, $\mathrm{CO}_{2}$, mine wastes) as well as on geotechnical hazards and risks. He has over 150 publications to his credit. He has been repeatedly invited as keynote speaker or lecturer and regularly acts as a consultant as well as a reviewer for several scientific committees, peer review journals and funding agencies as well as he serves on the editorial board of international journals.

Robert Gracie is an Associate Professor with the Department of the Civil and Environmental Engineering at the Universityof Waterloo (UW). He completed his $\mathrm{PhD}$ at Northwestern University on the simulation of deformation and fracture of solids in 2009, prior to which he spent two years with Natural Resources Canada conducting analysis of the interactions between ice, soil and offshore pipelines. At UW, he teaches courses in Solid Mechanics, Finite Element Analysis and Nonlinear Computational Mechanics and carries out research in the development of numerical methods to simulate the deformation and fracture of solids and the flow of fluids. He is known for his work on the development and application of the extended finite element method (XFEM), which has been developed specifically to simulation fracture, dislocations and multiphase flow. He has 27 journal articles on related topics. His current research projects include developing new simulation technologies for multiphase-phase flow during carbon sequestration, hydraulic fracturing of rock masses and microscale plasticity. 
Anthony Heyes is an Associate Editor of Environmental and Resource Economics and has been on the editorial boards of various journals including the Journal of Environmental Economics and Management and the Journal of Regulatory Economics. He is or has been a Fellow of ENCORE, University of Amsterdam, Nuffield College, Oxford, an S.T. Lee Fellow at the University of Wellington, a Senior Research Fellow at UCL and a CARR Fellow at the LSE. Outside academia, he has been a member of the Advisory Panel of HM Department of Environment, Farming and Rural Affairs (DEFRA) since 1999 and has provided advice or training to many parts of UK government including (HM Treasury, Home Office, Ministry of Justice, the Cabinet Office, etc.) the OECD, European Commission and private sector.

Daniel Krewski is a Professor of Epidemiology and Community Medicine at the University of Ottawa, where he also serves as Scientific Director of the McLaughlin Centre for Population Health Risk Assessment. His research interests include epidemiology, biostatistics, health risk assessment and risk management. He is a Fellow of the Society for Risk Analysis, the American Statistical Association and a national affiliate of the US National Academy of Sciences. He holds the Natural Sciences and Engineering Research Council of Canada Chair in Risk Science at the University of Ottawa.

\section{Introduction}

Since the pioneering report of the National Research Council (1983) on Risk Assessment in the Federal Government: Managing the Process, risk assessment and risk management processes related to technologies and technological change have evolved significantly, with enhancements to initial approaches for addressing health and environmental risks (Krewski et al., 2007; Leiss et al., 2010). Jardine et al. (2003) and the National Research Council (2009) emphasised that risk assessment and risk management activities should support the decision making needs of the specific risk context. There has also been an increased emphasis on communication of the technical analyses involved in risk assessment and management to much broader audiences in order to try to improve the level of confidence in and acceptance of the ultimate decisions based on them (Leiss et al., 2010). Another key characteristic of many of the most complex risk issues that we face today is that they are shared by a mix of nations around the world (sometimes all of them, as is the case with climate change) and that effective international coordination of risk management decision making in an age of increasing global economic integration is both desirable and necessary.

Articles in this Special Issue consider wide ranging risk assessment and management issues relevant to future CCS implementation. In introducing these issues, Leiss and Krewski (2019) identify ten major factors within three broad categories (Table 1). The key finding is that major risk issues have been proactively identified and characterised by industry, government and non-government organisations. While each of these issues could be the single subject of a Special Issue, the individual papers included herein consider selected aspects of these issues in more depth. 
Table 1 Ten major factors in risk assessment and risk management of CCS

\begin{tabular}{|c|c|c|}
\hline \multicolumn{2}{|c|}{ Risk factors } & Title (authors) of contribution in this Special Issue \\
\hline \multicolumn{3}{|c|}{ Government and industry factors } \\
\hline \multirow[t]{4}{*}{1} & Competent regulatory oversight & $\begin{array}{l}\text { Risk management frameworks for CCS: a global } \\
\text { perspective (Larkin et al., 2019d) }\end{array}$ \\
\hline & & $\begin{array}{l}\text { Alberta's approach to the transfer of liability for } \\
\text { carbon capture and storage projects (Bankes, } \\
\text { 2019) }\end{array}$ \\
\hline & & $\begin{array}{l}\text { The evolution of regulatory practice for CCS } \\
\text { projects in Canada (Larkin et al., 2019c) }\end{array}$ \\
\hline & & Canadian context in the present article \\
\hline \multirow[t]{2}{*}{2} & $\begin{array}{l}\text { Adequate risk assessment and risk } \\
\text { management frameworks }\end{array}$ & $\begin{array}{l}\text { Risk management frameworks for CCS: a global } \\
\text { perspective (Larkin et al., 2019d) }\end{array}$ \\
\hline & & Canadian context in the present article \\
\hline 3 & Supportive public policy architecture & Canadian context in the present article \\
\hline \multicolumn{3}{|c|}{ Environmental risk factors } \\
\hline 4 & $\begin{array}{l}\text { Adequate site-specific } \\
\text { characterisations of geological } \\
\text { formations for CCS storage sites } \\
\text { worldwide }\end{array}$ & $\begin{array}{l}\text { Potential technical hazards associated with four } \\
\text { North American carbon capture and sequestration } \\
\text { projects (Sarkarfarshi et al., 2019) }\end{array}$ \\
\hline 5 & The possibility of leakage in storage & $\begin{array}{l}\text { Uncertainty in risk issues for carbon capture and } \\
\text { geological storage: findings from a structured } \\
\text { expert elicitation (Larkin et al., 2019b) }\end{array}$ \\
\hline 6 & $\begin{array}{l}\text { Credible monitoring of storage site } \\
\text { performance }\end{array}$ & $\begin{array}{l}\text { Risk management in carbon capture and } \\
\text { geological storage: insights from a structured } \\
\text { expert elicitation (Larkin et al., 2019a) }\end{array}$ \\
\hline \multicolumn{3}{|c|}{ Socio-economic factors } \\
\hline 7 & Economic costs & $\begin{array}{l}\text { The economic evaluation of the benefits and costs } \\
\text { of carbon capture and storage (Heyes and Urban, } \\
\text { 2019) }\end{array}$ \\
\hline \multirow[t]{2}{*}{8} & $\begin{array}{l}\text { Public perceptions of risks and } \\
\text { benefits }\end{array}$ & $\begin{array}{l}\text { Risk communication and public engagement: the } \\
\text { foundations of public acceptability (Leiss and } \\
\text { Larkin, 2019) }\end{array}$ \\
\hline & & The present article \\
\hline \multirow[t]{2}{*}{9} & $\begin{array}{l}\text { Information provision, effective } \\
\text { communication and stakeholder } \\
\text { engagement }\end{array}$ & $\begin{array}{l}\text { Risk communication and public engagement: the } \\
\text { foundations of public acceptability (Leiss and } \\
\text { Larkin, 2019) }\end{array}$ \\
\hline & & The present article \\
\hline 10 & $\begin{array}{l}\text { Social and public acceptability, } \\
\text { including the use of decision support } \\
\text { mechanisms }\end{array}$ & $\begin{array}{l}\text { Improving decision-making processes for carbon } \\
\text { management initiatives (Campbell-Arvai et al., } \\
\text { 2019) }\end{array}$ \\
\hline
\end{tabular}

Risk assessment and risk management (RA/RM) frameworks for CCS have been developed in both a regulatory and non-regulatory context since the publication of the Special Report on Carbon Capture and Storage by the Intergovernmental Panel on Climate Change (IPCC, 2005). Based on the global compendium and comparative analysis undertaken by Larkin et al. (2019d), major frameworks are often value-chain 
specific. Each contains at a minimum a list of considerations for health or environmental RA/RM during project planning and implementation; more elaborated frameworks contain detailed methodological considerations. Mandatory requirements in leading jurisdictions include the European Union Directive on the Geological Storage of Carbon Dioxide (European Union, 2009) and United Nations Framework Convention on Climate Change, Modalities and procedures for carbon dioxide capture and storage in geological formations as a Clean Development Mechanism (United Nations Framework Convention on Climate Change, 2011). Elaborated non-regulatory guidance has been published by the US National Energy Technology Laboratory (National Energy Technology Laboratory, 2013, 2017a, 2017b, 2017c, 2017d) and DNV GL (Det Norske Veritas, 2010b, 2010c, 2012, 2013), as well as through web-based resources maintained by the Global Carbon Capture and Storage Institute (GCCSI, 2019). Collectively, these frameworks offer valuable guidance on how to move forward with the deployment of CCS technology in a safe and effective manner.

In their examination of the evolution of regulatory practice regarding CCS in Canada, Larkin et al. (2019c) found that oversight of integrated CCS projects (both saline aquifer and enhanced oil recovery) is value chain specific. Technical risk assessment has been completed for an increasing range of environmental and human health issues in capture, transport, injection and storage, using well-established approaches. Global risk estimation has not been completed for CCS and monitoring is identified as the principal risk management option. One area of ongoing concern, discussed further by Leiss and Larkin (2019) is a lack of transparency in risk communication.

With respect to technical risk issues in CCS performance and containment, Sarkarfarshi et al. (2019) provide an illustrative taxonomy of potential hazards based on international standards and publicly available application and review documents for three North American carbon capture and sequestration projects and one enhanced oil recovery (EOR) project. Six major potential events are described in detail: $\mathrm{CO}_{2}$ (carbon dioxide), $\mathrm{H}_{2} \mathrm{~S}$ (sulphur dioxide) or brine leakage from the reservoir during injection or storage; $\mathrm{CO}_{2}$ or $\mathrm{H}_{2} \mathrm{~S}$ leakage during transportation; release of hazardous gases or materials (other than reservoir and pipeline, e.g., $\mathrm{NO}_{2}$ (nitrogen dioxide) and $\mathrm{PM}_{2.5}$ (fine particulate matter) during capture plant operations); surface uplift; induced seismicity; and, unforeseen limitations in site storage capacity or well injectivity. Diagrams illustrate potential causal relationships between the triggers of the major hazardous event, the hazards and potential adverse consequences. For CCS activities (capture, transportation, well drilling, $\mathrm{CO}_{2}$ injection, short-term and long-term storage), Sarkarfarshi et al. (2019, Supplementary Information) provide a database of potential events, including a short description, the occurrence probability, magnitude and potential adverse consequence(s).

Larkin et al. (2019a, 2019b) provide findings from a structured expert elicitation on relative risk and uncertainty judgements for potential hazards in injection and storage and risk management of low probability high impact (LPHI) events. As an outstanding issue for CCS, Koornneef et al. (2012) suggested that ongoing uncertainty in injection and storage components of integrated projects has the potential to become a bottleneck for wide-scale implementation of CCS, if not properly addressed. While the insights gained from this expert elicitation are not applicable to a specific project, the findings assist in better understanding a number of difficult decision challenges anticipated in future project evaluation and approval processes. The empirical data may also provide motivation for further scientific deliberations to achieve objective judgements on CCS risk issues. 
For issues in risk assessment, experts' suggested an increasing uncertainty for the likelihood of minor, major and catastrophic $\mathrm{CO}_{2}$ leakage in capture, transport and injection during the operating period ( $0-50$ years), with virtual certainty of some minor leakage in capture at the lower limit of the credible range (5th percentile). The experts' judged that major $\mathrm{CO}_{2}$ leakage that would most likely result in measurable environmental or public health impact was the same over three time periods, approximately 1 in 103 . The experts also considered safe storage lifetimes to be quite long, with $95 \%$ of facilities expected not to fail for almost 13,000 years. The experts ranking of technical, environmental and health risk in capture, transport, injection and storage did not separate strongly and systematically. The likelihood and severity of hazards associated with well leakage, injection, intrinsic storage and induced storage circumstances were elicited using a five-point Likert scale previously used by Polson et al. (2012). Leakage from unknown and unlocatable wells was the only hazard to score high risk based on the risk ranking cutoffs used in the analysis of the elicitation results.

With respect to risk management the expert elicitation considered the effectiveness of six risk management options (site selection, well integrity studies, emergency response plan, monitoring, automatic shut-down system and training) for three georisks and two human health LPHI events: large migration out of pore space; caprock fracture; induced seismic event $\mathrm{M}>4$; massive fatal release of $\mathrm{CO}_{2}$ resulting in human fatalities; and catastrophic injection wellhead failure. Site selection and monitoring emerged as the preferred risk management options for georisks and were considered 'very' effective measures; the median expert response also suggested storage site monitoring should continue for 92 years. With the exception of site selection, all risk management options were considered 'very' or 'extremely' effective for both massive fatal release and catastrophic wellhead failure. The elicitation also quantified, in a preliminary way, judgements for the emphasis of risk management on human health compared with environmental protection in injection and storage activities; as well as mandated as opposed to voluntary cost allocations for environmental and human health protection during injection operations and the storage period.

The choice to implement CCS as a technological mitigation strategy for climate change transcends technological issues in performance and containment. Social risk issues consider legal questions on project liability. Bankes (2019) examines different categories of liability associated with a CCS storage facility, with emphasis on the transfer of post-closure liability from project developers to the Crown. In Alberta, a post-closure stewardship fund, has been established to collect fees per tonne $\mathrm{CO}_{2}$ injected during operations in order to pay for future post-closure (mostly monitoring) operations and risk of orphan sites. Third party tort liability is not, however, an eligible expense.

Heyes and Urban (2019) evaluated the benefits of CCS with respect to $\mathrm{CO}_{2}$ emissions avoided, with reference to the social cost of carbon (SCC) values that remain a component of policy analysis in Canada and the USA. They define the SCC as the 'benchmark' against which alternative carbon emissions reduction methods, including sequestration, are compared. If the SCC is greater than the technological cost to avoid a tonne of $\mathrm{CO}_{2}$ into the atmosphere, then it is deemed to pass a cost-benefit test. Their analysis finds lower benefits than costs from large scale CCS implementation, but sometimes by a small margin; moreover, the results can be sensitive to alternative analytic assumptions.

Campbell-Arvai et al. (2019) reviewed five challenges in decision making about carbon management options. Behavioural and perceptual obstacles may introduce 
systemic bias. Other issues relate to the complexity of carbon management problems themselves: neglecting objectives and performance measurement criteria; the propensity to search for singular solutions and in doing so, also neglecting a discussion of the full range of trade-offs among solutions; and preferences that support decisions are fundamentally constructive in nature. Their paper also offers a decision-making tool that can improve the quality of carbon management decisions.

Leiss and Larkin (2019) further explore risk communication and public engagement as foundations to public acceptability at the project level - a theme that underpins the integrated risk management framework for CCS proposed here. This paper suggests that a successful sequence of social interactions begins with public perception of the risks and benefits of CCS generally, followed by effective communication of these at the project level and credible public engagement, ultimately resulting in a transparent decision making process.

In this article, the prevailing public policy for CCS is presented as the backdrop to potential implementation as a mitigation option for climate change (Section 2). The Canadian regulatory context is also discussed, with an absence of an elaborated framework for how RA or RM should be completed under federal or provincial jurisdiction (Section 3). The attributes and practical dynamics of the proposed integrated risk management framework described in Section 4 should be of increasing interest to stakeholders as they strive for successful implementation: the IRMF provides a transparent process with improved risk-based decision inputs and a greater likelihood to identify acceptable risk control options. Section 5 considers approaches to managing the potential risk of CCS, considering regulatory, economic, advisory, technological and community-based risk management options, as suggested by Krewski et al. (2014).

\section{Canadian policy context}

Through collaboration between industry and government for over a decade, Canada has been a leader in CCS research and in deploying demonstration projects for CCS as an approach to climate change mitigation. The need for supportive financial and regulatory conditions was identified in the CCS Technology Roadmap (Natural Resources Canada, 2006) and the ecoEnergy CCS Task Force Report (2008). Over $\$ 3 B$ has been allocated through federal and provincial public funding, in addition to industry dollars (Government of Canada, 2011), with ongoing funding opportunities related to clean technologies (Natural Resources Canada, 2019).

Other federal efforts have focused on regulatory clarity under the Canadian Environmental Protection Act, 1999, such as the approved reduction of carbon dioxide emissions from coal-fired generation of electricity regulations (Environment Canada, 2018) and proposed regulations limiting carbon dioxide emissions from natural gas-fired generation of electricity (Government of Canada, 2018b). Coal-fired electricity generation is being phased out by 2030 (a ten-year earlier deadline than originally stipulated) (Government of Canada, 2016c) with a transition to lower- or non-emitting sources of electricity, including fossil-fuel power with CCS. A 420 tonnes of $\mathrm{CO}_{2}$ per GWh performance standard is being applied to new coal-fired units and those that will reach the end of their economic life within this timeframe. The intent is to apply the same performance standard to new and significantly modified natural gas-fired units (Government of Canada, 2018b). 
Adherence to such regulations is inevitably included in the calculations being made with respect to Canada's commitment to reduce emissions under the Paris Agreement (Government of Canada, 2016a; United Nations Framework Convention on Climate Change, 2015). Consistent with the coal-fired generation regulation, Saskatchewan's Boundary Dam project, primarily an EOR project, is acknowledged in the Pan-Canadian framework for clean growth and climate change (PCF) (Government of Canada, 2016d) as a positive way to reduce emissions in the electricity sector. Implementation of the Greenhouse Gas Pollution Pricing Act, the carbon pricing regime described in the PCF, could have further implications for CCS, beginning with $\$ 10$ per tonne in 2019 and rising by $\$ 10$ per year to $\$ 50$ per tonne in 2022 .

At the provincial level, British Columbia approved its Climate Action Plan in 2008 with goals to reduce GHG emissions by $33 \%$ by 2020 and $80 \%$ by 2050 from 2007 levels (Government of British Columbia, 2008a). The Greenhouse Gas Reductions Target Act (Government of British Columbia, 2014) requires that progress reports are completed every two years, with a finding that the 2012 interim target was achieved. The plan includes a revenue neutral carbon tax - now $\$ 30 /$ tonne - and will hold this price until the rest of Canada catches up. BC's 10-year Natural Gas Strategy includes production increases (British Columbia Ministry of Energy and Mines, 2012) and, as discussed in Section 3.4, a process to develop a CCS-specific regulatory policy framework (RPF) (Government of British Columbia, 2016; Province of British Columbia, 2014a, 2014b). This reflects BC's viewpoint for CCS and CCS-EOR to be key drivers for $\mathrm{CO}_{2}$ emissions mitigation.

Alberta's policy context for CCS has several components. Direct investment in CCS includes funding to the Quest Carbon Capture and Storage Project and Alberta Carbon Trunk Line (Larkin et al., 2019c), for which there is an ongoing requirement for the proponents to share technical information and lessons learned (Alberta Energy, 2018a). The province completed a regulatory framework assessment for CCS in 2013 (Alberta Energy, 2018b), described in detail in Section 3. Wide ranging recommendations resulted from the multi-stakeholder process for technical, environmental, safety, monitoring and closure issues for CCS. Implementation of the province's climate leadership plan (Government of Alberta, 2015) could also see CCS used to reduce emissions from coal fired plants that operate past 2030. In advance of the federal price on carbon, Alberta enacted the Specified Gas Emitters Regulation in 2007, applicable to large industrial emitters of GHGs, then replaced by the Carbon Competitiveness Incentive Regulation (carbon levy and rebate program) in 2017, beginning with \$20/tonne and having increased to \$30/tonne in 2018 (Government of Alberta, 2018).

In Saskatchewan, the aforementioned Boundary Dam project is this province's principle investment in CCS. Additional research is being undertaken at the Petroleum Technology Research Centre's Aquistore sequestration project, as well as potentially through CCS implementation at SaskPower's Shand Power facility.

In Nova Scotia, the legislature passed the Environmental Goals and Sustainable Prosperity Act unanimously in 2007 (Province of Nova Scotia, 2012) and a Climate Action Plan in 2009 (Nova Scotia Government, 2009). The target for GHG emissions reductions is $5 \mathrm{Mt} / \mathrm{year}$ by 2020 , with caps on electricity emissions taking effect in 2010, 2015 and 2020. A joint venture consortium, CCS Nova Scotia, between the Province, Nova Scotia Power Inc. and Dalhousie University, completed research on the elements of 
capture, transport and storage, as well as overarching issues of the environment, regulatory and legal, public awareness and risk management (CCS Nova Scotia, 2015). In order to better understand the geology, this group completed field research on the Sydney sub-basin as a potential site for a CCS project.

Table 2 Storage type and rated capacity $\left(\mathrm{MtCO}_{2}\right)$ for Canadian large scale integrated projects

\begin{tabular}{|c|c|c|c|}
\hline $\begin{array}{l}\text { Large scale integrated } \\
\text { project, sector and } \\
\text { province }\end{array}$ & Project phase & $\mathrm{EOR}\left(\mathrm{MtCO}_{2}\right)$ & $\begin{array}{c}\text { Saline } \\
\text { sequestration } \\
\left(\mathrm{MtCO}_{2}\right)\end{array}$ \\
\hline $\begin{array}{l}\text { Weyburn-Midale } \\
\text { (US capture; Canadian } \\
\text { EOR) } \\
\text { Saskatchewan }\end{array}$ & Operational & $\begin{array}{c}\text { 3/yr } \\
17 \text { since inception } \\
30-40 \text { projected } \\
(@ 2030) \\
\text { [Possibly 25 additional } \\
\text { storage, post EOR } \\
\text { operations] }\end{array}$ & \\
\hline $\begin{array}{l}\text { Boundary Dam } \\
\text { Coal fired electricity } \\
\text { Saskatchewan }\end{array}$ & Operational & $\begin{array}{c}1.0 / \mathrm{yr} \\
30 \text { total @2045 }\end{array}$ & \\
\hline $\begin{array}{l}\text { Alberta Carbon Trunk } \\
\text { Line - Industry } \\
\text { Alberta }\end{array}$ & $\begin{array}{l}\text { Construction } \\
\text { (Operational } \\
\sim 2019 \text { ) }\end{array}$ & $\begin{array}{c}1.5-2.0 / \text { yr initial } \\
14.6 / \text { yr flow capacity }\end{array}$ & \\
\hline $\begin{array}{l}\text { Shell Quest Project } \\
\text { Industry } \\
\text { Alberta }\end{array}$ & Operational & & $\begin{array}{c}1.2 / \mathrm{yr} \\
27 \text { total @2040 }\end{array}$ \\
\hline $\begin{array}{l}\text { Enbridge Fort Nelson - } \\
\text { Industry } \\
\text { British Columbia }\end{array}$ & Feasibility/planning & & $\begin{array}{c}2.2 / \mathrm{yr} \\
\sim 66 \text { total @30 yrs }\end{array}$ \\
\hline Total & & $\begin{array}{c}5.5-6.0 / \mathrm{yr} \\
>60-75 \mathrm{Mt} \mathrm{EOR} \\
\text { Possibly } 30-40 \mathrm{Mt} \\
\text { future storage }\end{array}$ & $\begin{array}{c}1.2-3.4 / \mathrm{yr} \\
\sim 27-93 \mathrm{Mt} \text { total }\end{array}$ \\
\hline
\end{tabular}

\section{Source: Larkin (2017)}

In terms of project development, Canadian saline sequestration and CCS-EOR large scale integrated projects (LSIPs) are rated to capture approximately $6.4 \mathrm{MtCO}_{2}$ equiv/yr (Table 2), equivalent to about $3 \%$ of this country's emissions reduction target of approximately $225 \mathrm{MtCO}_{2}$ equiv/yr (megatonnes equivalent per year) by 2030. As discussed by Larkin et al. (2019c), CCS-EOR has been underway since the 1990s at Saskatchewan's Weyburn-Midale operations. The Shell Quest project is one of four saline aquifer sequestration projects worldwide (GCCSI, 2018). Feasibility studies for a second project, the Fort Nelson CCS Project in British Columbia (proposed by Spectra Energy, now merged with Enbridge) were financed in part by the Government of Canada's ecoEnergy Technology Initiative ${ }^{1}$. Boundary Dam, Saskatchewan, is the first and only large scale power plant CCS-EOR project. Furthermore, Alberta's Carbon Trunk Line is coming on stream with a large capacity of $14.6 \mathrm{MtCO}_{2} / \mathrm{yr}$, a transport pipeline for EOR injection purposes for emissions sourced at a fertiliser plant, oilsands upgrader and from additional as yet unidentified industrial sites. 
Table 3 Potential CCS applications and related $\mathrm{CO}_{2}$ emissions

\begin{tabular}{|c|c|c|c|c|}
\hline \multirow[t]{2}{*}{ Potential CCS application ${ }^{\mathrm{b}}$} & \multicolumn{3}{|c|}{$\begin{array}{l}\text { Actual and estimated } \mathrm{GHG} \\
\text { emissions \% of Canadian total } \\
\left(\mathrm{MtCO}{\text { equiva })^{\mathrm{a}}}^{2}\right.\end{array}$} & \multirow{2}{*}{$\begin{array}{c}\text { Approximate LSIP } \\
\text { contribution to emissions } \\
\text { reductions (rated capacity) }\end{array}$} \\
\hline & 2013 & 2020 & 2030 & \\
\hline $\begin{array}{l}\text { Electricity sector - western } \\
\text { provinces; Nova Scotia } \\
\text { (Ontario and Quebec do not } \\
\text { burn coal) }\end{array}$ & $\begin{array}{c}\sim 12 \% \\
(85)\end{array}$ & $\begin{array}{c}\sim 10 \% \\
\text { (74) }\end{array}$ & $\begin{array}{c}\sim 7 \% \\
(58)\end{array}$ & $\begin{array}{c}1.35 \% 2020 \\
1.72 \% 2030 \\
(1 \mathrm{Mt}) \\
\text { Boundary Dam }\end{array}$ \\
\hline $\begin{array}{l}\text { Oil and gas sector - } \\
\text { western provinces (fossil } \\
\text { energy used in oil and gas } \\
\text { production and refining) }\end{array}$ & $\begin{array}{l}\sim 25 \% \\
(179)\end{array}$ & $\begin{array}{c}\sim 27 \% \\
(210)\end{array}$ & $\begin{array}{l}\sim 29 \% \\
(242)\end{array}$ & $\begin{array}{c}2-2.3 \% 2020 \\
1.8-2 \% 2030 \\
(4.3-4.9 \mathrm{Mt}) \\
\text { Quest, ACTL, Fort Nelson }\end{array}$ \\
\hline $\begin{array}{l}\text { Emission intensive trade } \\
\text { exposed (EITE) industry - } \\
\text { cement, steel (production } \\
\text { across Canada, but with } \\
\text { concentration in Ontario } \\
\text { and Quebec }{ }^{1} \text { ); fertiliser } \\
\text { (west) }\end{array}$ & $\begin{array}{c}\sim 10 \% \\
(76)\end{array}$ & $\begin{array}{c}\sim 10 \% \\
(76)\end{array}$ & $\begin{array}{c}\sim 13 \\
(107)\end{array}$ & $\begin{array}{c}0.8 \% 2020 \\
0.5 \% 2030 \\
(0.585 \mathrm{Mt}) \\
\text { Nutrien Redwater Fertilizer } \\
\text { portion of ACTL }\end{array}$ \\
\hline
\end{tabular}

Notes: averall in Canada, an estimated $79 \%$ of GHG emissions is $\mathrm{CO}_{2}$. There is

insufficient information to calculate the $\mathrm{CO}_{2}$ gas component of these projections.

${ }^{b}$ Weyburn Midale EOR excluded because capture facility is in the USA.

${ }^{1}$ Location of cement facilities: http://www.cement.ca/en/Economic-

Contribution.html; Location of steel facilities: http://www.canadiansteel.ca/wpcontent/uploads/2016/05/Steel_Facilities_Map.pdf.

Source: based on data from Government of Canada (2016b)

Potential further applications of CCS in the Canadian context are presented in Table 3, where estimated emissions from CCS sectors are provided for the 2020 and 2030 time horizons. The North American Carbon Storage Atlas (North American Carbon Atlas Partnership, 2012) identified 188 large stationary sources of $\mathrm{CO}_{2}, 71$ for electricity production and the rest listed as industrial sites. As a percentage of national total emissions, the electricity sector is projected to decrease to approximately $7 \%$; the oil and gas sector to increase to approximately $27 \%$; and the emission intensive trade exposed (EITE) sector (steel, cement, fertiliser production) also to increase to about $13 \%$ of emissions (Government of Canada, 2016b). Although the increase in the latter two sectors is approximately the same number of Mt between 2020 and 2030 (31 Mt), the percentage increase is greater for EITE than for the oil and gas sector $(41 \%$ increase compared with 15\%) (Table 3). International Energy Agency (IEA) analysis for industrial applications of CCS indicates Canada has a high trade exposure impact for methanol, iron and steel and cement, with CCS having a low, medium and high impact on production costs, respectively (IEA, 2018).

Table 3 also indicates a western provincial bias for CCS development within the electricity and oil and gas sectors. As evident from the list of Canadian projects to date (Table 2), these are located in the western provinces where the long history of oil and gas development supports industrial capture, pipeline transport, injection and storage phase activities of CCS. The Canadian West is also a prime storage region, given the large extent of the Western Canadian Sedimentary Basin (Bachu, 2003). However, project locations could see CCS expand to more populated regions, such as Ontario and Quebec, 
if Canada is to address emissions from the EITE sector across the country. Although sedimentary basins exist (Bachu, 2003), these regions have less familiarity with pipelines and wells and realising what are perceived to be acceptable risk control options may be more challenging. Indeed, proponents and regulators experienced public resistance to fossil-fuel related pipeline proposals such as Energy East in 2017.

Ongoing policy deliberations will consider how Canada will meet its Paris Agreement commitments and Canadian policy makers and wide ranging stakeholders, including industry, may yet identify CCS as the most preferable and cost effective mitigation option for point sources (IEA, 2015a, 2016). It is anticipated that fossil fuels will continue to be the largest component of the global energy mix, but that CCS may be the only large-scale technological process to mitigate emissions through 2050. However, L'Orange Seigo et al. (2014a) and CMC Research Institutes and Pembina Institute (2019) reported on limited knowledge about CCS in Canada, concluding that public education is necessary in support of informed decision making.

A background research paper prepared for the First Ministers' Specific Mitigation Opportunities Working Group (2016) listed alternative policy tools for electricity generation and large industry sectors. While CCS-related 'accelerated coal phase-out' and 'abatement and sequestration' is priced between $\$ 50-\$ 100 / \mathrm{t}$ (along with other mitigation options at this cost range), the Working Group report also identified mitigation policy tools for these sectors at higher and lower cost ranges (Specific Mitigation Opportunities Working Group, 2016). Implementing the IRMF presented in Section 4 may be critical to CCS within and outside western Canada, because if early projects have early setbacks, whether in terms of performance, containment, market, or risk perception, private and public stakeholders could abandon this technology.

\section{Canadian regulatory context}

The review and approvals for energy-related industrial development falls primarily within provincial jurisdiction in Canada. However, federal government authority does apply to Federal Lands, the North, where interprovincial matters exist within federal jurisdiction and where projects cross international boundaries. Krupa (2011) provided a first assessment of the legal framework for CCS in Canada.

As noted in Section 2, large scale CCS project development has been limited to two western provinces, Alberta and Saskatchewan. With a focus on environmental and human health assessment, this section is therefore limited to federal provisions in project assessment, as well as those in three provincial jurisdictions: Alberta, Saskatchewan and British Columbia. BC is also included because a feasibility assessment has been completed for Enbridge's Fort Nelson CCS Project ${ }^{1}$. For an analysis of the application of the Canadian provisions to four large-scale integrated projects, see Larkin et al. (2019c).

With respect to Indigenous groups in Canada, a 2014 Supreme Court of Canada ruling found that while economic development can still proceed on aboriginal land where Title is established, this requires that the development has the consent of the First Nation and, failing that, that the government must make the case that development is pressing and substantial and that it has met its fiduciary duty to the Aboriginal group (Supreme Court of Canada, 2014). 


\subsection{Canadian federal government}

Prior to July 2012, Canadian CCS projects were subject to the Canadian Environmental Assessment Act (CEAA) (Government of Canada, 2012b) when there was a potential financial contribution through the federal ecoEnergy Technology Initiative or Clean Energy Fund administered by Natural Resources Canada. This applied to Canadian projects to date. The goals of this Act were (among others): to ensure that projects were considered in a careful and precautionary manner ${ }^{2}$ to avoid significant adverse environmental effects; to encourage responsible authorities to take actions that promote sustainable development and thereby achieve or maintain a healthy environment and a healthy economy; and, to ensure opportunities for timely and meaningful communication and consultation with Aboriginal peoples and the public. The National Energy Board (NEB) also implemented the Act, having jurisdiction for pipelines crossing international and interprovincial boundaries. NEB regulations classified $\mathrm{CO}_{2}$ pipelines as a type of commodity pipeline with no specific standards, where terms and conditions were determined on an ad hoc basis, as guided by applicable procedures for other pipelines and supplemented by specific analysis of the individual applications (IEAGHG, 2010).

The CEAA was amended in 2012 and referred to as CEAA2012 until 2019, at which time the legislation was replaced through An Act to enact the Impact Assessment Act and the Canadian Energy Regulator Act, among other provisions. The purposes of the CEAA2012 remained similar to CEAA but its application changed. Under CEAA2012 (Government of Canada, 2012a) project-types included in the regulations required proponents to submit a project description to the Canadian Environmental Assessment Agency at which time a determination was made whether a federal environmental assessment was required. Potentially regulated 'physical activities' that could have been part of a CCS project include an oil or gas facility in a federally managed wildlife area; a fossil fuel-fired electrical generating station over $200 \mathrm{MW}$ in size, or greater than $50 \%$ expansion resulting in $200 \mathrm{MW}$ or more; expansion of a heavy oil or oils ands processing facility of defined capacity; and increased production capacity of more than $35 \%$ for an oil refinery, including a heavy oil upgrader of prescribed input capacity. The Minister for the Environment and Climate Change may also have designated a project not identified in regulations if there was the potential for environmental effects in areas of federal jurisdiction or public concerns about such effects. With respect to regulated requirements for cooperation and communication with Aboriginal peoples, the definition of 'environmental effects' included changes to health and socio-economic conditions, physical and cultural heritage, current use of land and resources for traditional purposes and any structure, site or thing that is of historical, archaeological, paleontological, or architectural significance. The NEB remained responsible for interprovincial and international pipelines.

While CEAA applied to several Canadian CCS projects considered by Larkin et al. (2019c), CEAA2012 did not apply to a Canadian CCS projects because no new project was proposed during its period. At the time of writing, the regulations under the new Impact Assessment Act (IAA) are undergoing consultation, including the project list, as are regulations governing activities of the newly established Canadian Energy Regulator. Among other provisions, the IAA (Government of Canada, 2019): 
- Created the single government impact assessment agency to lead assessments and coordinate crown consultations with indigenous peoples.

- Provides for assessment of environmental, health, social and economic effects of designated projects.

- Enables the Minister for the Environment or designate to approve projects that are likely to cause certain effects if deemed in the public interest, after taking into account impacts on rights of Indigenous peoples, and other factors.

- Establishes an early planning and engagement phase.

- Establishes timelines for impact assessments and related decisions.

- Continues with opportunities for public participation and funding.

- Sets out the factors to be taken into account, including impacts on Indigenous peoples.

- Provides for interjurisdictional cooperation.

- Provides for transparency in decision-making, including use of a public registry of scientific and other information taken into account.

- Enables the minister to set conditions, including mitigation measures.

- Provides for assessment of cumulative effects on a regional basis, including assessment of federal policies, plans and programs, and of issues that may be relevant to a project through strategic assessments.

- Sets out requirements for an assessment of environmental effects of non-designated projects that may be proposed on federal lands or outside Canada.

\subsection{Alberta}

One CCS project is operating in Alberta (Quest) and one project is being built (Alberta Carbon Trunk Line). Until October 2014, Alberta Ministry of Environment and Parks (AEP), formerly the Ministry of Environment and Sustainable Resource Development (ESRD), administered the Environmental Protection and Enhancement Act (EPEA) (Province of Alberta, 2010b) and Water Act (Province of Alberta, 2014) as they would apply to the potential effects of projects on land and water. The EPEA and accompanying regulations describe which activities require environmental impact assessment approvals and the process for obtaining them. Individual categories of activities include waste management; substance release; conservation and reclamation; miscellaneous (pesticides, designated materials, water wells); and potable (drinking) water. There are mandatory, exempted and discretionary project types; or, where an activity is not specifically listed in the Regulation, an EIA process may be triggered when referred by another Environment Director or by the Proponent who may request a decision on the need for an EIA report. There are six related regulations, two Codes of Practice and 12 listed Standards and Guidelines.

Since 2014, upstream oil and gas regulatory functions under these acts are administered by the Alberta Energy Regulator (AER) [formally the Alberta Energy Resources and Conservation Board (ERCB)]. The AER is a quasi-judicial administrative 
tribunal acting as the single regulator of energy development, from application and exploration, to construction and development and abandonment, reclamation and remediation. This includes allocating and conserving water resources, managing public lands and protecting the environment over the entire life cycle of hydrocarbon resource development. Energy-related project applications are posted and updated on the regulators' website.

The AER has been regulating the disposal, storage and injection of fluids to underground geologic formations in Alberta for over 20 years. CCS projects have been treated as acid gas disposal activities under its Directives (Bankes and Ference, 2009). An application to dispose $\mathrm{CO}_{2}$ would likely be approved if the AER is satisfied that disposal will not impact hydrocarbon recovery; the disposal fluid will be confined to the injection formation; offset owners within $1.6 \mathrm{~km}$ of the disposal well(s) have been consulted, with no objections or concerns to the disposal scheme (unit operators, approval holders, well licensees); and the applicant has the right to dispose into the requested formation.

The regulatory framework for CCS includes the Oil Sands Conservation Act (Province of Alberta, 2013b) applied to capture activities, the Oil and Gas Conservation Act (OGCA) (Province of Alberta, 2017) applied to storage activities and several Directives (Alberta Energy Regulator, 2018a): Directive 051, Injection and Disposal Wells, Directive 056, Energy Development Applications and Schedules applied to well and pipeline development (pipeline design is based on CSA Z662-07: Oil and Gas Pipeline Systems), Directive 065, Resources Applications for Oil and Gas Reservoirs applied to enhanced oil recovery schemes (EOR) and disposal/storage where $\mathrm{CO}_{2}$ is considered an acid gas, Directive 071, Emergency Preparedness and Response and other relevant Guides and Directives that apply to waste facilities and upstream oil and gas authorisations and consultation requirements.

Applications are posted publicly and AER hearings are scheduled where community concern is not resolved through the Appropriate Dispute Resolution process (Alberta Energy Regulator, 2013). Interveners are accredited based on the location of their land holdings and the potential for a direct and adverse effect within a designated environmental protection zone. Fluker (2009) suggested that the then-ERCB did not address the socio-ecological impacts of energy projects because of its narrow interpretation of who meets the test to obtain standing and request a hearing. Salomons and Hoberg (2014) provide examples and discuss concerns for the application of AER's 'directly affected' standard, an issue analysed by Larkin et al. (2019c). As a component of their Integrated Decision Approach, the AER is revising requirements for public consultation through its Participant Involvement Initiative (Alberta Energy Regulator, 2018b) with a draft Directive posted in 2019 (Alberta Energy Regulator, 2019).

The AER webpage also provides links to specified acts and regulations administered by other ministries, such as the EPEA (https://www.aer.ca/regulating-development/ rules-and-directives/acts-regulations-and-rules). Where applied, EIA examines a project to determine what the environmental, social, economic and health implications may be. A decision is made by the regulator as to whether the project is in the public interest and sets specific conditions under which the project can operate. There is a follow up program to monitor project implementation.

Alberta has also enacted several CCS-specific regulatory provisions. Through the Carbon Capture and Storage Statutes Amendment Act (Province of Alberta, 2010a), an amendment to the Mines and Minerals Act (MMA) (Province of Alberta, 2013a) and the Carbon Sequestration Tenure Regulation under the MMA (Province of Alberta, 2011), 
instruments define and grant pore space, establish minimum depth for injection (greater than 1,000 m) and manage long-term liability. Monitoring, measurement and verification (MMV) plans and closure plans are required in relation to a carbon sequestration lease. These plans must be approved and updated every three years, including management of long term liability. There is no specific reference or guidance on RA/RM, except for the MMV plans. However, the MMA enables RA to be required through regulation, as part of a $\mathrm{CO}_{2}$ storage permit application (IEA, 2014).

In 2013, Alberta completed a detailed Regulatory Framework Assessment (RFA) for CCS (Alberta Energy, 2018b). The goals were to review and develop regulations for $\mathrm{CO}_{2}$ sequestration that are comprehensive and transparent; to contribute to the acceleration of CCS activities in the province; and to underpin greater public acceptance of CCS projects. A multi-stakeholder, expert-led process considered technical, environmental, safety, monitoring and closure issues. The process focused on CCS for sequestration, as it was determined that CCS for EOR required its own review, including transitioning from EOR to CCS.

Background reports prepared for the working groups included: Review of Carbon Capture and Storage Environmental Assessment and Project Approval Requirements in Ex-Alberta Jurisdictions; Literature Review and Assessment of Potential Impacts of Emissions from Carbon Capture and Storage Projects; Carbon Capture and Storage Leakage Scenario Assessment and Gap Analysis of Alberta Mitigation and Remediation Plan Requirements; Public Engagement and Stakeholder Consultation Assessment; and a Public Safety Survey for CCS. (Not all of these continue to be available through a web search).

The RFA Report included 71 individual recommendations and 9 conclusions, now being considered by the Ministry of Energy for potential implementation (Alberta Energy, 2018b). A detailed status report on implementation is not published within four topic areas: applications, approvals and regulatory framework; risk assessment, monitoring and technical requirements; public consultation and notification, surface access and public safety; and site closure and long term liability. The RFA was extensive in terms of both process and outcomes.

Risk-related recommendations suggest:

- RA guidelines, deemed integral to the MMV and Closure plans, be iterative, systematic, technically defensible and transparent, with a publicly accessible process

- modelling and simulations be undertaken (as applicable on a site-specific basis) to evaluate and predict the behaviour of the $\mathrm{CO}_{2}$ sequestration complex and inform the RA

- MMV records (including all iterative updates and comparisons of predicted behaviour of the sequestered $\mathrm{CO}_{2}$ with measured performance) be retained for the life of the project to support MMV plans and closure certificate applications

- non-technical risks related to public acceptance of MMV be identified and addressed by project proponents.

The reporting also suggested that the entire RM process be incorporated into the regulatory framework, including 'informal assessment', although this assessment was not defined. It was also recommended that levels of acceptable risk be developed on a case-by-case basis, between the regulator and proponent (other stakeholders were not 
identified); that mandatory EIA be undertaken during a three-year review of its application to CCS; that the public safety priority focus on transportation and injection; and that a detailed RA would inform MMV focused on $\mathrm{CO}_{2}$ capture, injection and storage.

The RFA also noted that air emissions from $\mathrm{CO}_{2}$ capture processes (i.e., amine-based systems) and impacts to groundwater from $\mathrm{CO}_{2}$ sequestration operations are both less well understood and thus require further study. Other recommendations are to develop environmental protection zone (EPZ) requirements specific to CCS projects for transportation and injection only; and the review of CSA Z741-12: Geological Storage of Carbon Dioxide (CSA Group, 2012), in order to inform a decision on whether the standard, or parts of it, should be adopted by the province (Alberta Energy, 2018b).

With respect to communication and outreach, the report and appendices refer to the importance of transparency and public understanding of CCS as a new technology. The development of a CCS Regulatory Guidance Document and industry-wide minimum requirements specific to CCS were recommended, with the possibility of enhancing the consultation and notification process for all stakeholders normally undertaken for oil and gas activities.

\subsection{Saskatchewan}

In Saskatchewan, a wide variety of project types are submitted by proponents to the Ministry of Environment (SaskMoE) for review under The Environmental Assessment Act (EAA) (Government of Saskatchewan, 2018). As described (Government of Saskatchewan, 2014a), the environmental assessment (EA) branch first administers a screening process of the proponent's technical proposal to arrive at a determination whether the project is a 'development' under the Act. If deemed necessary by the EA branch, the proposal will be distributed more broadly for a technical review. Assessment criteria for any project, operation, or activity or any alteration or expansion of any project, operation or activity include:

- the effect on any unique, rare or endangered feature of the environment

- substantial utilisation of any provincial resource and in so doing pre-empt the use, or potential use, of that resource for any other purpose

- emission of any pollutants or by-products, residual or waste products which require handling and disposal in a manner that is not regulated by any other Act or regulation

- widespread public concern because of potential environmental changes

- new technology that is concerned with resource utilisation and that may induce significant environmental change

- significant impact on the environment or necessitate a further development which is likely to have a significant impact on the environment.

This process also serves to identify the range of non-environmental legislative and regulatory requirements. The EA branch has an option to require the proponent to complete public consultation or additional studies and the proponent is given the opportunity to answer any outstanding questions. The subsequent Ministerial Determination will either: 
1 provide a clearance for the project, based on the description and proposed environmental protection commitments outlined in the proposal and the clarifications and restrictions developed through the review process

2 require an EIA.

The EIA process requires the proponent to prepare a Terms of Reference or scoping document that identifies areas for detailed study including ecological, socio-economic and cultural issues. An environmental impact statement is then prepared by the proponent and distributed for technical review. Proponents are encouraged to undertake public consultation. A formal public comment period is posted after the technical review; following which the Minister's decision is made - to approve, approve with terms and conditions, or refuse the application.

Once clearance or EIA approval is completed, the proponent may proceed to obtain other required permits and approvals for $\mathrm{CO}_{2}$ transport under the Pipelines Act and associated regulations (Government of Saskatchewan, 2011) and injection and EOR under the Oil and Gas Conservation Act (OGCA) (Government of Saskatchewan, 2014b). However, this is not mandatory under either legislation; some projects may be reviewed under EAA screening prior to or in parallel with the OGCA approval process.

The main purpose of the OGCA is to enable the greatest possible ultimate recovery of provincial oil or gas reserves, while protecting the environment with respect to operations of the oil and gas industry. The OGCA has been applied to $\mathrm{CO}_{2}$-enhanced oil recovery (EOR) operations. In 2011, an OGCA amendment (Government of Saskatchewan, 2014b) expanded regulation-making powers and clarified oversight for non-oil-and-gas substances, in particular with respect to the injection, storage and sequestration of carbon dioxide and other greenhouse gases in subsurface caverns. The Minister is authorised to make orders respecting:

- the containment, storage, handling, transportation, treatment, processing, recovery, reuse, recycling, destruction and disposal of oil and gas waste and non-oil-and-gas waste

- the conditions under which drilling and producing operations may be carried out in environmentally sensitive areas and any special measures to be taken in those operations

- well closures, decommissioning, abandonment and site reclamation

- contributions to Oil and Gas Orphan Fund in the event that the owner of a well is unable to implement its obligations with respect to a specific well or facilities.

There are requirements for the owner/operator to ensure post-closure protection to prevent $\mathrm{CO}_{2}$ leakage, as well as to properly decommission and remediate the surface area. However, ongoing monitoring or testing for leakage is not normally required from the licensee, except where reasonable risk exists; the Ministry will then require an on-going monitoring program. Details for making this determination were not available, but depend on an assessment of the circumstances. Remediation for leakage at a decommissioned and abandoned well site is the responsibility of the licensee in perpetuity.

Lastly, communications and outreach with stakeholders are not prescribed in Saskatchewan. Experience by the SaskPower proponent and Petroleum Technology 
Research Centre, for the Boundary Dam capture project (Larkin et al., 2019c), appeared to follow best practices, but no specific regulatory requirements.

\subsection{British Columbia}

In British Columbia, most broadly, the Environmental Assessment Act (Government of British Columbia, 2017a) applies to major projects or facilities and the Environmental Management Act (Government of British Columbia, 2017b) aims to protect human health and the quality of water, land and air with respect to waste management and contaminated sites. The associated Waste Discharge Regulation (Government of British Columbia, 2017d) lists industries, trades, businesses, activities and operations that require authorisation to introduce waste into the environment. To date, $\mathrm{CO}_{2}$ has not been listed as a waste product.

More specifically, the mandate of the single-regulator British Columbia Oil and Gas Commission (BCOGC) is to provide for the sound development of the oil and gas sector by fostering a healthy environment, a sound economy and social well-being; to conserve petroleum and natural gas resources; to ensure safe and efficient practices; and to assist resource owners to participate equitably in the production of shared pools of petroleum and natural gas. The Commission regulates the exploration and use of storage reservoirs, facilities, wells and provincial pipelines, as well as undertakes education and communication programs in order to advance safe and efficient practices in technological development. Community and industry expectations and process flowcharts are available (BC Oil and Gas Commission, 2017).

While no large scale CCS project is operating in British Columbia, several Acts and regulations would apply. The BC Petroleum and Natural Gas Act (Government of British Columbia, 2012) provides a definition of a storage reservoir and enables its tenuring, with provision for permitting, leases (including disposal well purposes), spacing, pooling and Crown Reserves. The Oil and Gas Activities Act (OGAA) Section 75 enables application for an underground storage facility (Government of British Columbia, 2008b). The BCOGC has adopted the Canadian Standards Association Standard Z741 Geological Storage of Carbon Dioxide (CSA Group, 2012) under the Drilling and Production Regulation of the OGAA (Government of British Columbia, 2017c).

The $\mathrm{BC}$ government recognised that these provisions were not designed to manage issues of long term $\mathrm{CO}_{2}$ storage development. A CCS-specific regulatory policy framework is underway with a stated purpose "to identify and address any regulatory gaps; ensure that CCS is done safely to protect the public and the environment; and to provide transparency in CCS development" (Province of British Columbia, 2014b, p.2). Among the proposals relevant to environment and health RA/RM, the discussion paper suggested that a CCS storage reservoir lease application would include: site characterisation details; $\mathrm{CO}_{2}$ stream composition; a description of measures to prevent significant leakage, unintended migration or other irregularities, as well as corrective measures and contingency plans in such an event; a proposed monitoring plan; health and safety emergency response plan; and community and First Nations' engagement plan, including consultations conducted at the time of application. The discussion paper also suggested establishing a CCS review board (Storage Reservoir Stewardship Board) to verify these inclusions and that the Board would refer to third party experts to review site characterisation data, validate site risk assessments, monitoring and verification programs and mitigation plans. The proposed monitoring plan would be results-based and informed 
by site-specific risk assessments (Province of British Columbia, 2014a). Information on the status of implementing the recommendations is not posted publicly.

\section{Integrated risk management framework for carbon capture and storage in the Canadian context}

Significant contributions in the form of elaborated risk assessment and risk management frameworks for CCS have been published by both regulatory and non-regulatory organisations worldwide (Larkin et al., 2019d). This work suggests that: storage site selection and characterisation is an effective approach to reduce risk; the use of the well accepted standard for a 3- or 4-step risk assessment process; an iterative approach to monitor and re-assess risk; and the use of accessible and transparent processes. Some recommend risk ranking using expert facilitated workshops, but only with respect to site selection and risk management (CSA Group, 2012; Det Norske Veritas, 2012; World Resources Institute, 2008). Comprehensive risk estimation is not yet promoted. Monitoring has been identified as the key option for assuring containment and performance, including an iterative process to update modelling and subsequent monitoring efforts. However, regulatory and non-regulatory suggestions for contingency planning for major incidents are not yet well developed. While RA/RM considerations such as characterisation of uncertainty, stakeholder communication and consultation and the goal of transparency are discussed in a limited way in the regulatory context, some non-regulatory guidance is focused solely on these activities (Forbes et al., 2010; National Energy Technology Laboratory, 2017b).

Overall, RA/RM for CCS in North America has been less prescribed than in European-based jurisdictions (Larkin et al., 2019d). For example, in contrast to the United Nations Framework Convention on Climate Change (2011) mandatory elaborated requirements for capture, transport, storage and post-injection, the US Underground Injection Control (UIC) Class VI Well Program (promulgated in 2010) does not include a mandatory requirement for RA/RM (US Environmental Protection Agency, 2011). US Environmental Protection Agency voluntary guidance is, however, extensive. Moreover, the Class VI Well Program is linked to the Greenhouse Gas Reporting Program, Subpart RR, Geologic Sequestration of Carbon Dioxide. For the latter, a monitoring, reporting and verification plan must be submitted for review and approval (Dixon et al., 2015). In Canada, as described in Section 3, amendment to the Alberta Energy Resources Conservation Act and Mines and Minerals Act to facilitate CCS (approved in 2011) did not include reference or guidance on RA/RM, except for a required measurement, monitoring and verification (MMV) Plan, but without elaboration.

In Canada, we are in the midst of moving on from CEAA2012 with a new legislative framework, the Impact Assessment Act and the Canadian Energy Regulator Act. Subsequent regulations will be forthcoming. As proposed at the time of this writing, the mandate of the Government of Canada, the Minister, the Agency and federal authorities would include application of the precautionary principle, with one of the purposes of the new Act directing federal authorities to exercise powers in a careful and precautionary manner to avoid significant adverse effects within federal jurisdiction (Government of Canada, 2018a). Implementation of Alberta's CCS Regulatory Framework Assessment is ongoing, while the implementation of British Columbia's CCS Regulatory Policy Framework is as yet unknown. 
Under these circumstances, application of a robust integrated risk management framework will serve to support successful deployment of additional CCS projects in Canada and elsewhere. In turn, this will allow this technology to achieve the valuable contribution to climate change mitigation that has been anticipated since its inception (IEA, 2015a).

\subsection{Previous attempts at integration}

Previous attempts at integration in risk assessment and risk management have been made at the conceptual and project level. Bowden and Rigg (2004) published the first major overview of risk assessment for $\mathrm{CO}_{2}$ projects, testing a conceptual approach in the context of four sites in Australia. The proposed approach was to build on the familiar FEP (feature, event, process) analysis, which is focused first on the understanding of complex failure modes, then on scenario analysis, process modelling (the behaviour of injected $\mathrm{CO}_{2}$ under various physical conditions) and finally consequences analysis for health, safety and environmental parameters. In addition, transparency in the risk assessment process was enhanced, so as to "provide an interface with the wider community and allow stakeholders to assess whether the process is safe, measurable and verifiable, and whether a selected alternative site would deliver cost-effective greenhouse benefits" (Bowden and Rigg, 2004, p.678). An independent and objective expert panel would carry out quantitative estimates of likelihood and consequences for selected risk scenarios and report their findings to the public and key stakeholders, following the risk identification and strategy using quantitative evaluation (RISQUE).

Risk assessment of $\mathrm{CO}_{2}$ capture, transport and storage is considered within the context of environmental impact assessment in a major study by Koornneef et al. (2012). Among other reasons, they argue that this larger context is important because $\mathrm{CO}_{2}$ capture at power plants entails 'cross-media impacts' which, for example, change the profile of other key atmospheric emissions (such as $\mathrm{NO}_{\mathrm{x}}$ and $\mathrm{NH}_{3}$ ) and produce an increase in water consumption and the creation of new waste by-products. In other words, risk assessments that focus exclusively on the transport, injection and underground storage of $\mathrm{CO}_{2}$ itself normally do not capture any associated cross-media impacts and thus may underestimate the overall magnitude of the environmental consequences of a CCS project. Table 10 in Koornneef et al. (2012, p.82) provides a summary of the key issues in the assessment of environmental interventions regarding $\mathrm{CO}_{2}$ capture, transport and storage. Given these additional complexities in the risk assessment of CCS projects, the authors recommend the utilisation of a "transparent process that demonstrates [to] the general public how risks and uncertainties are managed" (Koornneef et al., 2012, p.82).

Gerstenberger et al. (2013) presented an overview of methods and tools that are available for 'integrated risk assessment for CCS'. Both qualitative tools - including brainstorming, a risk register, structured expert elicitation and bow-tie diagrams - as well as probabilistic or quantitative tools are reviewed, with an indication how different tools may be phased-in during stages of a complex decision process. The authors strongly recommend in particular the use of an expert elicitation process in order to respond to the inevitable uncertainties and limited data available at the time decisions are made. Gerstenberger et al. (2013, p.2782) conclude on a note that is fundamental to the overall process: "A key component of an effective risk assessment is communication. The assessment should effectively communicate to varied stakeholders the current state of knowledge with respect to risk within the system." 
Multicriteria decision analysis (MCDA) is a familiar and well-tested method for taking a structured approach to the evaluation of risk, particularly for evaluating and ranking alternative solutions. Choptiany and Pelot (2014) and Choptiany et al. (2015) apply the MCDA approach to CCS problems, such as choosing among competing $\mathrm{CO}_{2}$ storage sites and optimising mitigation measures for risk reduction. The articles develop this approach for hypothetical coal-fired power plants involving post-combustion $\mathrm{CO}_{2}$ capture, pipeline transport and storage in depleted oil reservoirs. The decision model development has the standard MCDA features, including hierarchy of objectives, elicitation of utility functions, criteria weighting, scoring and sensitivity analysis. In Choptiany and Pelot (2014), the authors argue that this method enables an interactive engagement process with stakeholders who can participate as decision-makers in study process and can provide a "transparent assessment method by which to choose among competing projects." In Choptiany et al. (2015) results further indicated functionality and positive responses from experts in government, environmental non-government organisations, research and industry who participated in the case study.

The most comprehensive risk assessment project level documentation on a group of proposed CCS sites, the Final Risk Assessment Report for the FutureGen Project Environmental Impact Statement, was issued in 2007 by the US Department of Energy (US Department of Energy, 2007). The project included a coal-fired generation plant upgrade with an oxy-combustion technology, capture of 1.1 million tons of $\mathrm{CO}_{2}$ (more than $90 \%$ of carbon emissions), criteria air quality contaminant emissions reductions to near-zero levels and pipeline transportation of the sequestered gases to an underground storage site. The risk assessments for four proposed sites, two in Illinois and two in Texas, evaluated both human-health and environmental adverse effects; human-health effects were considered separately for workers and the public. The release scenarios encompassed two categories, pre-sequestration releases from pipelines and wellheads as well as post-sequestration releases through caprock, faults and wellbores. More than a dozen separate failure modes were considered in the release scenarios and the probabilities of at least one failure were estimated quantitatively for each one. Thousands of pages of text and illustrations, including methodologies, were made available on a publicly-accessible website. Subsequently the site in Meredosia, Illinois, was chosen for the project. However, the project is suspended, with federal funding cancelled in 2015.

For the Illinois Basin-Decatur Project (IBDP), Hnottavange-Telleen et al. (2011) noted that a risk management program for geological sequestration sites should aim to maximise the chance of project success "by assessing, monitoring, minimising all risks in a consistent framework" (p.4044). An FEP-based expert elicitation methodology was used to rank risks and scenarios were identified that would provide the "tangible and temporal malignant chains of events against which interventions - risk reductions - can be designed" (p.4051). The authors' stressed that risks as perceived by a variety of interested parties and stakeholders are no less important than those identified by experts and that adequately addressing all risks is indispensable for project success.

Bowden et al. $(2013 a, 2013 b)$ reported two related studies dealing with the IEAGHG Weyburn-Midale $\mathrm{CO}_{2}$ monitoring and storage project in Saskatchewan, Canada. The first was labelled a 'geosphere risk assessment' and the second, a 'biosphere risk assessment'. The biosphere is defined as 'the air, soils, rivers, lakes and groundwater and everything contained therein, that lie above the base of the Cretaceous-Tertiary aquifers'. The base of the biosphere occurs at a general depth of $150 \mathrm{~m}$ in the Weyburn-Midale Project area and the geosphere as everything below that depth. The geosphere assessment used the 
RISQUE method (Bowden and Rigg, 2004) to identify in quantitative terms the 'containment risk' - possible leakage of $\mathrm{CO}_{2}$ from underground storage - as well as further research needs and risk reduction opportunities. The containment target was set at $99 \%$ of stored $\mathrm{CO}_{2}$ over the first 1,000 years, at a confidence level of $80 \%$. An expert panel concluded that this target would be met; however, it also identified well pathways as the greatest risk to containment and recommended a review of well abandonment practices to address this risk. The biosphere study used "the outputs (pathways, likelihoods and $\mathrm{CO}_{2}$ mass) from geosphere risk assessment to identify the general physical and chemical effects on the fundamental biosphere components (groundwater, surface water, soil, air) and the consequential impacts on organisms, habitat, amenity and public safety" (Bowden et al., 2013a, p.S291). These effects were reported in a semi-quantitative form and were put in the context of environmental impact assessment methods. The thorough public engagement strategy adopted the view that stakeholder perceptions are an important factor in project success and sought direct stakeholder inputs (including values) on a wide range of specific issues associated with the biosphere risk assessment process. It also used a 'socially acceptable risk' concept holding that "if risks are low enough, the community will accept them."

The project application, review and approval of the Shell Quest saline sequestration project in Alberta, Canada, included the identification and assessment of environmental and human health risks for each of capture, transport, injection and storage. Qualitative, semi-quantitative and quantitative methodologies were undertaken and the storage scheme was assessed by an Independent Panel Review. The 20-month process generated approximately 4,000 pages within 400 documents; however, transparency, in terms of ease of access and the fullest possible disclosure, was problematic. The subsequent regulatory decision by Alberta's Energy Resources Conservation Board (now the Alberta Energy Regulator) illustrates the risk management decision-making process (Energy Resources Conservation Board, 2012). This project is included in the detailed analysis of regulatory practice (Larkin et al., 2019c).

What is still lacking in a Canadian context is a response to the challenge posed in the articles by Gerstenberger et al. (2013) and Pawar et al. (2015), for effective communication with a broader range of stakeholders on the risk assessment and risk management of CCS projects which would help to foster further acceptance of this technology. Leiss and Larkin (2019) suggest a chain of social interactions begins with public perception of the risks and benefits of CCS generally; continues with effective communication of these at the project level; then involves robust and credible mechanisms for public engagement; and results in transparent decision making processes. As described in Larkin et al. (2019d), the 2012 Canadian Standards Association standard for CCS also stipulates that risk communication and consultation should specifically address the thoroughness, accuracy, transparency, traceability and consistency of the risk assessments and the nature and degree of understanding of known or perceived risk scenarios (CSA Group, 2012).

\subsection{Attributes and dynamics of IRMF in practice}

The proposed integrated risk management framework (IRMF) for CCS in the Canadian context supports both a systematic and transparent ten-step rational process for project proponents and regulators to follow, as well as a guide to ongoing opportunities for wide-ranging engagement with other government, quasi-government and 
non-government stakeholders at all stages (Figure 1): these features will help to ensure success in project implementation with improved risk-based decision inputs and a greater likelihood to identify acceptable risk control options. As examples, findings from the expert elicitation reported by Larkin et al. (2019b) provide valuable new insights on the difficult decisions related to short and long term hazard and risk issue uncertainties that need to be addressed.

Figure 1 Integrated risk management framework for carbon capture and storage in the Canadian context

\begin{tabular}{|c|c|c|c|c|c|c|}
\hline \multicolumn{3}{|c|}{$\begin{array}{l}\text { Government and } \\
\text { Quasi-government Stakeholders }\end{array}$} & $\begin{array}{c}\text { Federal/Provincial Regulators } \\
\text { Project Proponent }\end{array}$ & \multicolumn{3}{|c|}{$\begin{array}{l}\text { External Non-government } \\
\text { Stakeholders }\end{array}$} \\
\hline $\begin{array}{l}\text { International } \\
\text { Agencies }\end{array}$ & $\begin{array}{c}\text { Foreign } \\
\text { Governments }\end{array}$ & $\begin{array}{l}\text { Other Canadian } \\
\text { Government or } \\
\text { Indigenous Group }\end{array}$ & Core Organizations & $\begin{array}{l}\text { Directly } \\
\text { Impacted } \\
\text { Sectors }\end{array}$ & $\begin{array}{l}\text { Other External } \\
\text { Stakeholders }\end{array}$ & Public \\
\hline \multicolumn{7}{|c|}{ Risk Assessment Phase } \\
\hline \multirow[t]{3}{*}{$\begin{array}{l}\text { Regular } \\
\text { Contact }\end{array}$} & \multirow{4}{*}{ Notification } & $\begin{array}{l}\text { Notification } \\
\text { Info requests }\end{array}$ & $\begin{array}{l}\text { 1. Issue A wareness } \\
\text { 2. Review Policy and } \\
\text { Governance Context }\end{array}$ & $\begin{array}{l}\text { Ongoing } \\
\text { Activity }\end{array}$ & $\begin{array}{l}\text { Regular } \\
\text { Contact }\end{array}$ & \multirow{4}{*}{ Quest-Pembina } \\
\hline & & $\begin{array}{l}\text { Quest, ACTL, } \\
\text { Boundary Dam }\end{array}$ & $\begin{array}{l}\text { 3. Risk Dimension } \\
\text { Analysis }\end{array}$ & $\begin{array}{l}\text { Notification } \\
\text { Info requests }\end{array}$ & & \\
\hline & & $\begin{array}{l}\text { CEAA - Quest, } \\
\text { ACTL } \\
\text { NEB - W-M }\end{array}$ & 4. Risk Estimation & & Quest - DNV IPR & \\
\hline Notification & & Collaboration & $\begin{array}{l}\text { 5. Risk Control Options } \\
\text { Analysis }\end{array}$ & Collaboration & Fit for Purpose & \\
\hline \multicolumn{7}{|c|}{ Risk Management Phase } \\
\hline \multirow[t]{2}{*}{ Notification } & \multirow{5}{*}{ Communication } & Collaboration & $\begin{array}{l}\text { 6. Formal Consultation } \\
\text { Process }\end{array}$ & Communication & $\begin{array}{l}\text { Notification \& } \\
\text { Participation }\end{array}$ & $\begin{array}{l}\text { Notification \& } \\
\text { Participation }\end{array}$ \\
\hline & & $\begin{array}{l}\text { CEAA - Quest } \\
\text { and ACTL } \\
\text { Notification and } \\
\text { Collaboration }\end{array}$ & $\begin{array}{l}\text { 7. Risk Management } \\
\text { Decision }\end{array}$ & $\begin{array}{l}\text { Quest-AER } \\
\text { Decision }\end{array}$ & & \\
\hline \multirow{3}{*}{ Notification } & & $\begin{array}{l}\text { CEAA - Qvest } \\
\text { and ACTL } \\
\text { Notification and } \\
\text { Collaboration }\end{array}$ & $\begin{array}{l}\text { 8. Implementation } \\
\text { Sequence }\end{array}$ & & Communication & $\begin{array}{l}\text { Notification \& } \\
\text { Participation }\end{array}$ \\
\hline & & $\begin{array}{l}\text { CEAA -Quest } \\
\text { and ACTL } \\
\text { Notification }\end{array}$ & $\begin{array}{l}\text { 9. Monitoring and } \\
\text { Compliance Plan }\end{array}$ & Notification & Notification & $\begin{array}{l}\text { Notification \& } \\
\text { Particination }\end{array}$ \\
\hline & & $\begin{array}{l}\text { CEA.A - Quest } \\
\text { and ACTL } \\
\text { Notification and } \\
\text { Review }\end{array}$ & $\begin{array}{l}\text { 10.Evaluation, Review \& } \\
\text { Adjustment }\end{array}$ & Communication & Collaboration & $\begin{array}{l}\text { Notification \& } \\
\text { Particination }\end{array}$ \\
\hline
\end{tabular}

Notes: Types of stakeholder engagement at each step are for illustrative purposes only. Diamonds represent recommended independent external review. Examples from Canadian project approval processes are also indicated.

Source: Larkin et al. (2019c) 
The attributes and dynamics described below will also address three issues noted by Leiss et al. (2010) in their assessment of the continuing evolution of RM frameworks over the past 30 years. First, risk management frameworks have not included a mechanism to break down the distribution of authority for human health and environmental risk factors within the 'silos' of line departments at multiple levels of government. Second, particularly for global risk issues, mechanisms are not yet developed to adequately support opportunities for international collaboration in risk management. And third, some risk issues span extended time horizons, during which the capacity of agencies to manage risk at critical junctures needs to be supported (Leiss et al., 2010). Each of these issues is relevant to CCS, with integrated projects raising a number of complexities, including: wide ranging human health and environmental hazards spread over four value chain components; the place of CCS within the global issue of climate change mitigation; and the timeline of project implementation spread over decades, with the goal of permanent storage giving rise to intergenerational considerations.

The central panel in Figure 1 indicates the ten risk assessment and risk management steps that comprise the core of the framework. In the risk assessment phase these are: issue awareness; review of the policy and governance context; risk dimension analysis; risk estimation; and risk control options analysis. in risk management, the key steps include: a formal consultation process; risk management decision; implementation sequence; monitoring and compliance plan; and evaluation, review and adjustment. As indicated in Table 4, each of these steps involves a number of key components.

Two other notable features of the IRMF are the options for transparent integrated input by wide ranging stakeholders and the conduct of independent external review at selected junctures. With respect to the first of these two features, an extensive but possibly incomplete list of potential government, quasi-government and non-government stakeholders whose input may be integrated in different ways at various points has been developed (Table 5). As described in Section 3, core provincial government agencies responsible for project review and approvals in Canada's western provinces include single window regulators in Alberta and BC and the Ministry of Environment in Saskatchewan. The Canadian Environmental Assessment Agency and National Energy Board (under federal review, as noted above) may or may not be a regulator, depending on the project specifications. For a specific proposal, the lead proponent or industry partnership would also be identified.

The three left-hand panels indicate an integrated role for government and quasi-government agencies within Canada, foreign governments, or international partnerships. Within Canada, if the CEAA or NEB are not regulators for a project proposal, they would be included here. Other agencies include provincial ministries with a review function, such as for the environment, health, geological survey, or fisheries and oceans; interested and active provincial governments; the project's municipal and/or regional government(s); and potentially affected Indigenous groups (First Nations, Métis, or Inuit). The potential list of foreign government stakeholders includes active and interested jurisdictions where lessons may be learned from the Canadian experience in project approvals. A number of international agencies could be engaged because of their interest in tracking CCS developments given their support for the technology (such as the IEA, Intergovernmental Panel on Climate Change (IPCC), UN Framework Convention on Climate Change (UNFCCC)), or as a means of increasing understanding for a Canadian risk management process relative to other jurisdictions (such as the UNFCCC, OSPAR Commission for the protection of the marine environment of the north-east 
Atlantic and International Maritime Organization). Foreign government research institutes are also well established and included on the left hand panels of the framework.

Table 4 Major steps and key components in integrated risk management framework

\begin{tabular}{|c|c|c|c|}
\hline \multicolumn{2}{|c|}{ Major step in IRMF } & \multicolumn{2}{|r|}{ Key components } \\
\hline 1 & Ongoing surveillance & a & $\begin{array}{l}\text { Horizon scanning } \\
\text { Risk forecasting/foresight } \\
\text { Science updates }\end{array}$ \\
\hline 2 & $\begin{array}{l}\text { Review } \\
\text { policy/governance } \\
\text { context }\end{array}$ & a & $\begin{array}{l}\text { Domestic laws, regulations } \\
\text { International treaties and agreements } \\
\text { Relevant policies }\end{array}$ \\
\hline 3 & Risk dimensions analysis & $\begin{array}{l}\mathrm{a} \\
\mathrm{b} \\
\mathrm{c}\end{array}$ & $\begin{array}{l}\text { Number of unique risks } \\
\text { Potential for risk escalation } \\
\text { Initial risk communication }\end{array}$ \\
\hline 4 & Risk estimation & $\begin{array}{l}\mathrm{g} \\
\mathrm{h}\end{array}$ & $\begin{array}{l}\text { Hazard characterisation } \\
\text { Exposure characterisation } \\
\text { Determination of risk factors } \\
\text { Frequency estimation } \\
\text { Consequences estimation } \\
\text { Uncertainties specification } \\
\text { Risk class (probability x consequence matrix) } \\
\text { Risk ranking }\end{array}$ \\
\hline 5 & $\begin{array}{l}\text { Risk control options } \\
\text { analysis }\end{array}$ & a & $\begin{array}{l}\text { Domestic context } \\
\text { International context } \\
\text { Financing of options }\end{array}$ \\
\hline 6 & $\begin{array}{l}\text { Formal consultation } \\
\text { process }\end{array}$ & a & $\begin{array}{l}\text { Interim decisions (if required) } \\
\text { Presentation of risk assessment } \\
\text { Analysis of feedback }\end{array}$ \\
\hline 7 & $\begin{array}{l}\text { Risk management } \\
\text { decision }\end{array}$ & $\begin{array}{l}\mathrm{a} \\
\mathrm{b}\end{array}$ & $\begin{array}{l}\text { Risk control steps } \\
\text { Allocation of responsibilities } \\
\text { Risk communication strategy }\end{array}$ \\
\hline 8 & Implementation sequence & a & $\begin{array}{l}\text { Coordination of agencies } \\
\text { Memoranda of agreement } \\
\text { Targets and timeframes }\end{array}$ \\
\hline 9 & $\begin{array}{l}\text { Monitoring and } \\
\text { compliance plan }\end{array}$ & a & $\begin{array}{l}\text { Allocation of responsibilities } \\
\text { Inspections and reporting } \\
\text { Achieving risk control objectives }\end{array}$ \\
\hline 10 & $\begin{array}{l}\text { Evaluation, review and } \\
\text { adjustment }\end{array}$ & a & $\begin{array}{ll}\text { Agreed timeline for follow-up to verify predictions } \\
\text { i } & \text { IRMF steps for risk assessment } \\
\text { ii } & \text { IRMF steps for risk management }\end{array}$ \\
\hline
\end{tabular}


Table 5 Potential government, quasi-government and non-government stakeholders within a Canadian integrated project risk management process for carbon capture and storage

\begin{tabular}{|c|c|}
\hline Broad stakeholder type & Organisations \\
\hline \multicolumn{2}{|c|}{ Core stakeholders - centre panel (Figure 1); see also Section 3} \\
\hline $\begin{array}{l}\text { Canadian federal } \\
\text { government }\end{array}$ & $\begin{array}{l}\text { Possibly, but not always (see Section 3): Canadian Environmental } \\
\text { Assessment Agency, National Energy Board, Natural Resources } \\
\text { Canada }\end{array}$ \\
\hline Provincial government & $\begin{array}{l}\text { Regulator in provincial jurisdiction where project is undertaken. } \\
\text { Alberta Energy Regulator; Saskatchewan Ministry of Environment, } \\
\text { British Columbia Oil and Gas Commission }\end{array}$ \\
\hline Proponent & $\begin{array}{l}\text { Individual company or partnership within oil and gas industry, } \\
\text { coal-fired electricity generation, or emissions intensive trade exposed } \\
\text { industry }\end{array}$ \\
\hline \multicolumn{2}{|c|}{ Government and quasi-government stakeholders - left hand panel (Figure 1). } \\
\hline International agencies & $\begin{array}{l}\text { International Energy Agency, Intergovernmental Panel on Climate } \\
\text { Change, United Nations Framework Convention on Climate Change, } \\
\text { OSPAR Commission, International Maritime Organization, Carbon } \\
\text { Sequestration Leadership Forum, World Bank }\end{array}$ \\
\hline \multicolumn{2}{|l|}{ Foreign governments } \\
\hline $\begin{array}{l}\text { Foreign government } \\
\text { agencies and } \\
\text { associations }\end{array}$ & $\begin{array}{l}\text { European Union, US Department of Energy, US Environmental } \\
\text { Protection Agency, US various active State governments, US - } \\
\text { Canada Clean Energy Dialogue, Australia Commonwealth and State } \\
\text { governments, Norway, UK, other active CCS jurisdictions (e.g., } \\
\text { China, Brazil, Japan, South Africa, etc.) }\end{array}$ \\
\hline $\begin{array}{l}\text { International country- } \\
\text { based research institutes }\end{array}$ & $\begin{array}{l}\text { CATO2 - Netherlands, US-China Clean Energy Research Centre, } \\
\text { US Regional Carbon Sequestration Partnership Program, UK - } \\
\text { Carbon Capture and Storage Association, Australian Commonwealth } \\
\text { Scientific and Industrial Research Organization (CSIRO), Japan - } \\
\text { Research Institute of Innovative Technology for the Earth and others } \\
\text { (e.g., in Scotland, China, South Africa) }\end{array}$ \\
\hline \multicolumn{2}{|c|}{ Other Canadian government or Indigenous group } \\
\hline $\begin{array}{l}\text { Federal government } \\
\text { agencies }\end{array}$ & $\begin{array}{l}\text { Natural Resources Canada - Office of Energy Research and } \\
\text { Development, Canmet Energy, Energy Policy, Geological Survey of } \\
\text { Canada; Environment and Climate Change Canada; Health Canada; } \\
\text { Fisheries and Oceans Canada; National Research Council }\end{array}$ \\
\hline $\begin{array}{l}\text { Provincial government } \\
\text { review agencies and } \\
\text { others }\end{array}$ & $\begin{array}{l}\text { As named in individual jurisdiction: Ministry of Environment, } \\
\text { Energy, Health, Geological Survey, Active Provincial and Territorial } \\
\text { Governments, for instance the Saskatchewan Research Council, } \\
\text { Alberta Innovates, British Columbia Innovation Council and CCS } \\
\text { Nova Scotia }\end{array}$ \\
\hline Municipal government & Project location and regional representation \\
\hline Indigenous group & $\begin{array}{l}\text { First Nations, Métis, Inuit in project location and regional } \\
\text { representation }\end{array}$ \\
\hline
\end{tabular}


Table 5 Potential government, quasi-government and non-government stakeholders within a Canadian integrated project risk management process for carbon capture and storage (continued)

\begin{tabular}{|c|c|}
\hline Broad stakeholder type & Organisations \\
\hline \multicolumn{2}{|c|}{ External non-government stakeholder organisations - right hand panel (Figure 1) } \\
\hline $\begin{array}{l}\text { Directly impacted } \\
\text { industry sectors }\end{array}$ & $\begin{array}{l}\text { Oil and gas operators - e.g., Athabasca Oil Sands Project (Shell } \\
\text { Canada, Chevron Canada, Marathon Oil Canada Corporation), North } \\
\text { West Redwater Partnership (North West Upgrading Inc., Canadian } \\
\text { Natural Resources Ltd.), Enhance Energy, Santonia Energy, Swan } \\
\text { Hills SynFuels, Spectra Energy, Cenovus Energy, Apache Canada } \\
\text { Ltd; etc., Electricity - e.g., SASKPower, Sherritt, TransAlta, Nova } \\
\text { Scotia Power Inc; etc., Emission intensive trade exposed industry - } \\
\text { fertilizer, steel, cement, chemical; etc. }\end{array}$ \\
\hline \multicolumn{2}{|l|}{ Other external stakeholders } \\
\hline $\begin{array}{l}\text { International } \\
\text { membership } \\
\text { organisations }\end{array}$ & $\begin{array}{l}\text { Global Carbon Capture Storage Institute (GCCSI), International } \\
\text { Energy Agency, IEA Greenhouse Gas R\&D Programme, the } \\
\text { International Standards Organization, Carbon Capture and Storage } \\
\text { Association, Cooperative Research Centre for Greenhouse Gas } \\
\text { Technologies }\left(\mathrm{CO}_{2} \mathrm{CRC}\right) \text {, American Coalition for Clean Coal } \\
\text { Electricity }\end{array}$ \\
\hline $\begin{array}{l}\text { Canadian research and } \\
\text { industry organisations }\end{array}$ & $\begin{array}{l}\text { Petroleum Technology Research Centre, CMC Research Institutes, } \\
\text { Canadian Clean Power Coalition, Canadian Oil Sands Innovation } \\
\text { Alliance (COSIA), Coal Association of Canada, Canadian } \\
\text { Association of Petroleum Producers, Alternative Energy Association, } \\
\text { Clean Resource Innovation Network, Natural Gas Innovation Fund, } \\
\text { Canadian Energy Research Institute }\end{array}$ \\
\hline Universities & $\begin{array}{l}\text { UCL Centre for Law and Environment, } U \text { of Regina, } U \text { of } \\
\text { Saskatchewan, U of Alberta, U of Calgary, Other }\end{array}$ \\
\hline Major consultants & DNV GL, Schlumberger, Bluewave Resources \\
\hline $\begin{array}{l}\text { Larger non-government } \\
\text { organisations }\end{array}$ & Pembina Institute, World Resources Institute, Bellona, ZERO \\
\hline Public & $\begin{array}{l}\text { Local and regional non-government organisations and environmental } \\
\text { non-government organisations, individuals, experts, smaller } \\
\text { consulting firms, or watershed based organisations }\end{array}$ \\
\hline
\end{tabular}

The three right-hand panels categorise the range of non-government stakeholders that might be engaged in a decision making process. In Canada, directly impacted sectors include oil and gas operators, the electricity sector and emission intensive trade exposed industries (Section 2, Table 5). Other non-government stakeholders include representatives of the CCS member-based research community, selected universities, large environmental non-government organisations (ENGOs) and, in the public domain, local or regional NGOs or ENGOs, or individuals.

Integrated stakeholder engagement throughout the RA and RM steps will provide risk managers with a detailed picture of the risk management context worldwide. Interaction across the framework could include a continuum of activities such as notification, communication, participation, or collaboration, depending on the step in the process and the stakeholder in question. Such interaction and engagement is possible and desirable in order for input to provide clarity as to what is important, what is acceptable and what risk control options could be applied (Leiss et al., 2010). 
Opportunities for input in the form of independent external review are indicated by the diamond shapes included at various points in Figure 1. Bowden and Rigg (2004) suggested the use of an independent and objective expert panel to complete risk estimates and report the findings to stakeholders; Gerstenberger et al. (2013) strongly recommended expert elicitation to address uncertainties and limited data availability. Although expert elicitation has also been used to rank risks, Hnottavange-Telleen et al. (2011) emphasised that perceived risk (Krewski et al., 2012) may be equally important. Some RA/RM frameworks have also identified the use of expert facilitated workshops for risk ranking. More recently, $\mathrm{BC}$ identified the potential for third party experts in aspects of our framework's step 4 - to validate site risk assessments and step 9 - to review the monitoring and verifications programs and mitigation plans (Section 3). We propose that independent external review, including public engagement, extend to step 3 - risk dimension analysis, step 5 - risk control options analysis and step 10 - evaluation, review and adjustment (Figure 1).

The IRMF also draws on the Canadian experience in project review and approval. Based on analysis of regulatory practice (Larkin et al., 2019c), Figure 1 provides examples of where some key components of the IRMF have been implemented by project proponents and regulators to date. For example, for Shell Quest and Alberta Carbon Trunk Line (ACTL), the Canadian Environmental Assessment Agency was engaged in the steps entitled formal risk estimation, risk management decision, implementation sequence, monitoring and compliance plan and with an ongoing role in evaluation, review and adjustment. With respect to non-government engagement, Shell Quest solicited an independent review of their consultation process and risk estimation for the storage component and a member of the public hired an independent review of the hydrological risk estimation. An independent review also certified the project as fit-forpurpose.

While the Shell Quest application, review and approval process had positive attributes, such as the use of recognised methodologies with a multi-step risk assessment approach (step 4) and use of independent expert review, an analysis of regulatory practice also identified shortcomings (Larkin et al., 2019c). Recall that this project is the only true sequestration project in Canada and one of three worldwide. The process was difficult to follow, some risk assessments were incomplete or withheld and, while the review and decision for Quest was a public hearing process, participation was limited to landowners within the project's area of influence.

The level of detail provided in the IRMF contrasts existing regulatory and non-regulatory elaborated frameworks and guidance documents, these having a more limited focus on the detail to be completed in step 4 - formal risk estimation and the iterative process for monitoring in risk management (Larkin et al., 2019d). Furthermore, while risk communication has been addressed in some frameworks such as modalities and procedures for CCS as a clean development mechanism (United Nations Framework Convention on Climate Change, 2011), the National Energy Technology Laboratory (2017b) guidance on outreach and education and the World Resources Institute Guidelines for Community Engagement (Forbes et al., 2010), the right and left-hand panels illustrate the potential for transparent, extensive and ongoing opportunities to engage with a variety of stakeholders in a variety of ways throughout the risk assessment and management phases. Both the $\mathrm{BC}$ and Alberta regulatory review processes described in Section 3 identified transparency as an important goal. 
The IRMF could be used as a process checklist, where the responsibility to conduct various interactions with agencies and affected parties are recorded as having been completed. Similarly, in their review of RA/RM developments in the decade since publication of the IPCC Special Report on CCS (IPCC, 2005), Pawar et al. (2015, p.307) reiterated how "an effective communication approach needs to demonstrate how the risk assessment approach has effectively taken into account various stakeholder concerns during the assessment process, how the uncertainties have been handled, what impact uncertainties have on risks and how risk is managed via monitoring and mitigation actions". The use of the IRMF could include a record of proactive consultations with interested stakeholders, which could be publically available as the regulatory approval process proceeds.

We suggest that implementation of such a systematic, transparent and integrated process will accommodate the local context and support the outcomes of the risk-based decision-making process, namely to identify acceptable risk control options for a specific CCS site. Such a process is warranted, especially with options for climate change mitigation being scrutinised at the policy and project levels. Implementation of the IRMF would provide a greater opportunity to reach consensus and avoid ongoing controversies (such as experienced with Saskatchewan's Boundary Dam project and may be repeated as Canadian policy-makers decide what mitigation options are to be implemented). Opportunities for meaningful discussion on the costs, benefits, safety and contribution of CCS to mitigate climate change would be created and possibly play a role in public acceptance to support broad application of CCS technology. Furthermore, this could operationalise the recommendation of the Commission on Social Determinants of Health (2008), that climate change mitigation options not unnecessarily and unfairly negatively impact populations, nor exacerbate health equity through unintended effects.

In contemplating the application of the IRMF in other countries (IEAGHG, 2017), meaningful engagement with relevant stakeholders in other jurisdictions can be realised. While international government and quasi-government agencies may remain the same for projects in other jurisdictions (Table 5), key national or regional government and non-government stakeholders would be identified and integrated in the decision making process.

\subsection{Risk-based decision making}

Risk-based decision making and risk management of technologies and technological change should be based on four broad issue areas: well-established principles of risk management, economic analysis, sociopolitical considerations and risk perception (Krewski et al., 2014). These are important features of the context of a CCS project proposal and should underpin the IRMF's risk management activities to select and implement acceptable risk control options.

The ten decision-making principles of risk management were first proposed by Jardine et al. (2003):

a beneficence and non-maleficence (do more good than harm)

b natural justice (a fair process of decision making)

c equity (ensure an equitable distribution of risk)

d utility (seek optimal use of limited risk management resources) 
e honesty (be clear on what can and cannot be done to reduce risk

f acceptability of risk (do not impose risks that are unacceptable to society)

$\mathrm{g}$ precaution (be cautious in the face of uncertainty)

$\mathrm{h}$ autonomy (foster informed risk decision making for all stakeholders)

i flexibility (continually adapt to new knowledge and understanding)

$\mathrm{j}$ practicality (the complete elimination of risk is not possible).

Krewski et al. (2014) suggested that the importance of each of these principles could vary for each decision-making context and that their consideration may not lead to the same risk management conclusion. Integrated engagement from the outset, as depicted in the IRMF, might therefore be of benefit because stakeholders will have an opportunity to discuss the ten principles that could affect the decision making at three levels: first, the 'approach principles', namely beneficence/non-maleficence and/or precaution; the 'process principles', potentially choosing the emphasis between natural justice, equity, honesty, acceptability and autonomy; and the 'operational principles', including utility, flexibility and practicality of risk management options.

These principles of risk management and the broad issue of risk perception are closely linked for CCS at the project level and on an individual risk basis. Stakeholder engagement in the determination of the three levels of approach, process and operational risk management principles of greatest effect would help to build trust and a consensus could develop for the IRMF's decision-making process. Indeed, the importance of trust and fairness was found to have a bearing on public understanding and acceptability in risk management (Leiss and Larkin, 2019). CCS is in the particular position of dual roles for government, both as a proponent providing financial and policy support (Section 2) and as regulator [Section 3; see also Larkin et al. (2019c)]. Pawar et al. (2015, p.307) found that "while the GCS [geologic $\mathrm{CO}_{2}$ storage] field projects executed to date have taken into account the public perception risk (acceptance of the project), no documented GCS risk assessment application exists where the public perception risk has been explicitly addressed as part of a structured risk assessment approach." Risk assessment and risk management completed in a thorough, open and transparent way will help to build trust in the review and approval process, with associated benefits to risk acceptability.

Economic analysis as a broad area contributing to risk-based decision making is relevant at three scales for CCS. In the first instance, this would be completed in advance of a proponent's final investment decision on whether or not to proceed with a project. Second, once a decision to proceed is made, the risk management principle to seek utility through the optimal use of RM resources would manifest in economic analysis on an individual risk basis. Economic interest lies in "the extent to which a quantitative statement of monitorable project goals can reduce cost and improve stakeholder confidence" (Jenkins et al., 2015, p.343). At these two scales, implementation of the IRMF as a process would provide opportunities for varied stakeholder input to improve understanding and develop support for the economic analysis that underpins the choice to proceed with the project and the choices for risk management options. Furthermore, at the global level, Heyes and Urban (2019) considered more generally the benefits and costs of CCS as a mitigation strategy for climate change. Their conclusion, in reference to the social cost of carbon valuation used in Canada, is that the implementation of large 
scale CCS has lower benefits than costs, although sometimes with a small margin and that alternative assumptions can affect the calculations.

Two categories of risk management challenges related to the sociopolitical context for CCS are introduced by Leiss and Krewski (2019):

1 government and industry factors (discussed here for the Canadian context, including regulatory oversight [see also Bankes (2019)]: an adequate RA/RM framework (proposed here) and supportive public policy architecture (Section 2)

2 socio-economic factors: information provision, effective communication, stakeholder engagement and social and public acceptability through decision support mechanisms [aspects of which are considered by Leiss and Larkin (2019) and Campbell-Arvai et al. (2019)].

At the regional and national scale, Campbell-Arvai et al. (2019) suggested that "benefit perceptions might be susceptible to the national context where CCS is deployed... [possibly] due to differences in the national energy mix and energy policy." Indeed, Kern et al. (2016) analysed Alberta's positive political economy landscape as a critical feature in the successful application and development of the Quest project in Canada. Within the IRMF process, socio-political considerations in risk-based decision making can be more easily identified and addressed beginning at Step 1 and continuing through ongoing integrated engagement with wide-ranging government, quasi-government, external non-government and public stakeholders.

Full understanding of these four broad issue areas, that is, to consider well-established principles of risk management, risk perception, economic analysis and sociopolitical considerations underpin the complex risk management decision making context for CCS. Moreover, the most important of each of these will be different at each of three scales, namely the individual value chain component risk in capture, transport, injection and storage; the overarching project risk in a community and region; and, the societal/policy (global) domain. Within these scales, there will also be a myriad of stakeholders' points of view. With respect to project risk, Campbell-Arvai et al. (2019) reviewed behavioural and perceptual obstacles, as well as those associated with the complexity of carbon management problems themselves. Leiss and Larkin (2019) suggested that "the perception of benefits - or the failure to appreciate the benefits of CCS - may be more important than perception of the associated risks (where the normal case is the exact opposite)." With respect to the global domain at the time, L'Orange Seigo et al. (2014b) suggested the potential technical risks of CCS were not overly concerning to the public; rather, that the public exhibited greater uncertainty about the role of CCS in climate change mitigation. Once again, the opportunities for varied stakeholder engagement throughout the IRMF process will assist with creating the conditions for a positive outcome for the local and global community in CCS risk-based decision making.

\subsection{Risk management options for CCS}

Selected hazards associated with integrated CCS projects that could be addressed using a variety of risk management options are given in Table 2 [see Sarkarfarshi et al. (2019), for a more complete discussion of CCS hazards]. 
Table 6 Illustrative environmental and human health hazard taxonomy and risks for integrated CCS projects

\begin{tabular}{|c|c|c|c|}
\hline \multicolumn{4}{|c|}{ CCS value chain activity } \\
\hline Capture & Transport & Injection & Storage \\
\hline \multicolumn{4}{|c|}{ Physical hazards } \\
\hline \multicolumn{4}{|c|}{$\mathrm{CO}_{2}$ stream impurities } \\
\hline $\begin{array}{l}\mathrm{CO}_{2} / \text { amine/criteria } \\
\text { contaminant air } \\
\text { emissions }\end{array}$ & Pipeline failure & $\begin{array}{l}\text { Injection wellhead } \\
\text { or well casing } \\
\text { failure }\end{array}$ & $\begin{array}{l}\text { Unexpected plume } \\
\text { migration }\end{array}$ \\
\hline $\begin{array}{l}\text { Amine/criteria } \\
\text { contaminant } \\
\text { land/water }\end{array}$ & $\begin{array}{l}\text { Associated systems } \\
\text { failure }\end{array}$ & Caprock fracture & $\begin{array}{l}\mathrm{CO}_{2} \text {, brine or } \mathrm{CO}_{2} \\
\text { saturated brine migration } \\
\text { through caprock }\end{array}$ \\
\hline \multicolumn{4}{|c|}{ Induced seismicity } \\
\hline \multicolumn{4}{|c|}{ Direct surface leakage - well leakage or far field } \\
\hline \multicolumn{4}{|c|}{ Accidents, malfunctions, unplanned events (process upsets) } \\
\hline \multicolumn{4}{|c|}{ Human health and environmental hazards } \\
\hline \multicolumn{4}{|c|}{$\mathrm{CO}_{2}$ inhalation - occupational and/or public and/or wildlife morbidity/mortality } \\
\hline \multirow{2}{*}{\multicolumn{4}{|c|}{$\begin{array}{l}\text { Drinking water, soil, air contamination from amines, criteria contaminants, } \mathrm{CO}_{2} \text {, or brine } \\
\text { Unanticipated } \mathrm{CO}_{2} \text { leakage rate to atmosphere contributing to climate change }\end{array}$}} \\
\hline & & & \\
\hline \multicolumn{4}{|c|}{ Surface uplift or earthquake } \\
\hline
\end{tabular}

Developed as the REACT framework for risk management and population health (Krewski et al., 2007; Krewski et al., 2014), risk management options include potential actions in five domains:

- regulatory: government policies, legislation, guidelines, permits, or approvals for required action (three categories of statutes include products, emissions and natural environmental protection)

- economic: insurance, levies and other cost structures, designed as incentives to take action

- advisory: programs developed to encourage action, including communications, education and awareness

- community-based: public inception, support and commitment to take action, often volunteer-based

- technological: action through improved advances in technological abatement and in the case of CCS, an emphasis on monitoring

Further to the aforementioned four broad issues in risk-based decision-making, integrated stakeholder engagement, as depicted in the IRMF through notification, communication and consultation, at various steps as appropriate, could lead to discussions and decisions within these five categories of risk management options for CCS.

With respect to a regulatory approach, Wilson et al. (2003), Keith et al. (2005) and Wilson et al. (2008) were among the first to examine the kind of regimes that might provide a credible basis for risk-based decision making for CCS [see also Leiss (2009)]. 
With focus on regulatory oversight, Wilson et al. (2008, p.2782) suggested both that CCS needs to be done right, because a "single major accident, resulting from inadequate regulatory oversight, anywhere in the world, could seriously endanger the future viability of GS [geological storage]" and that "any regulatory framework to manage GS should therefore be adaptive, without compromising the basic objectives of safety and climate policy."

Requirements for site evaluation and monitoring and especially the latter, have since been identified as key to confirming the robustness of the assumptions built into the risk estimation within the risk assessment phase (National Energy Technology Laboratory, 2017a; Smith et al., 2011). Similarly, Pawar et al. (2015, p.307) suggested no $\mathrm{CO}_{2}$ storage site "should be permitted without significant characterization and regulatory scrutiny" and that where a site has a small chance of $\mathrm{CO}_{2}$ leakage, "permitting would be unlikely, that monitoring will always be required, and that approved injection parameters will minimize residual risk." Jenkins et al. (2015) further discussed the regulatory linkage between monitoring and verification, also suggesting a need to consider significant adverse events explicitly from evaluation through monitorable outcomes.

It is arguable whether an individual risk management option should be established by regulation rather than as an advisory or community-based approach. In tabular format, potential risk management options within each of the five REACT categories, as they may apply to value-chain activities, are provided in the supplementary material [online]. These options were identified from research by Larkin et al. (2019a) and Larkin et al. (2019c, 2019d) concerning the features of RA/RM frameworks worldwide, analysis of regulatory practice in the Canadian context and findings from an expert elicitation, as well as research reported in Gale et al. (2015). The suggestions cover wide-ranging approaches to be discussed and accepted within the risk management context in which the project is proposed. Minimum documentation requirements could also be identified. As suggested by this IRMF, Det Norske Veritas (2012) and the Independent Project Review of Shell's Quest Project (Det Norske Veritas, 2010a), a risk register would record all hazards, how each was considered and the chosen risk management option in order to instill completeness and transparency. Key risk management options include regulated baseline measurements, operations, emissions, monitoring and reporting activities; penalties, fines and liability funds; notification processes; community-based siting and emergency response planning; training and operations strategies; and monitoring technologies, alarms and shut down procedures. Given the wide ranging opportunities for stakeholder engagement, the IRMF would support clarity and development of acceptable risk control options.

While the application of the IRMF presented here is focused on sequestration, carbon capture utilisation and storage (CCUS) must also be considered. Worldwide, $76 \%$ of projects and $81 \%$ of the capture rate is CCS-EOR, with five of the next seven executing LSIPs being EOR project types (MIT, 2018). As indicated in Table 2, Canada has three such projects.

For project risk, an expert elicitation panel suggested the three storage options of saline aquifer sequestration, EOR and coalbed methane had similar relative risk (Larkin et al., 2019b). With respect to saline sequestration compared with enhanced oil recovery (EOR) operations, the median response for the percent of $\mathrm{CO}_{2}$ that can be expected to be retained for 1,000 years was virtually the same $(99.8 \%)$. However, there was greater uncertainty in the credible range for EOR, particularly at the 5\% (1 in 20) lower limit: 
$87 \%$ and $54 \%$ of injected $\mathrm{CO}_{2}$ was thought likely to be retained, respectively. Such uncertainty is clearly an important outstanding issue.

Indeed, the regulatory regimes for CCS-EOR projects are not as rigorous in terms of monitoring (identified as the key risk management option), verification and public reporting of $\mathrm{CO}_{2}$ stored. In Alberta, as elsewhere, industry is not required to demonstrate containment and performance (Jenkins et al., 2015), both of which are leading issues for the protection of the environment and human health. At the time, the Regulatory Framework Assessment in Alberta specifically excluded EOR because this activity requires a separate study. Additional amendments or new regulatory initiatives should be anticipated for these activities. In terms of storage benefit, accounting of CCS-EOR in climate change mitigation is being considered (IEA, 2015b; IEAGHG, 2016; Wong et al., 2013), as well as the potential costs (Godec et al., 2017) and technical challenges (Al Eidan et al., 2015) when a CCUS project may be converted to sequestration, as has been suggested for Weyburn-Midale in Saskatchewan (Table 2).

The current emphasis on CCS-EOR may be attractive to some stakeholders and publics because of the economic benefits to a project, but may not, however, encourage public acceptance of CCS for sequestration (Mabon and Littlecott, 2016). CCS-EOR projects are sometimes seen as not only enabling but also perpetuating a dependence on the fossil fuel economy for a longer timeframe. The range of supportive CCS stakeholders may begin to wane because real progress towards permanent geological sequestration may not happen fast enough. As well, there is currently heightened public scrutiny regarding the approval process and development of large energy-related projects in Canada, particularly for pipeline developments. Given the potential for CCS-EOR projects, perhaps regulated monitoring and reporting will help to ensure these projects are safe, reliable and positive contributions to emissions reductions in the short term. The broader issue concerning the ongoing use of fossil fuels is not resolved here.

\section{Conclusions}

Should Canadian industry and government policy and decision-makers choose to ramp up CCS as a climate change mitigation technology in suitable locations, the integrated risk management framework presented here provides a coordinated, rational pathway for project assessment and contribution to decision making. The IRMF is based on a welldeveloped sequence of steps in risk assessment and risk management that has evolved over several decades (Krewski et al., 2007; Leiss et al., 2010). Enhancements to previous attempts at integration include the deliberate and transparent integration of wide ranging stakeholders in government, industry, non-government organisations and the general public for the duration of the project, including the application, review, approval, operations, monitoring and evaluation periods. The IRMF also provides for independent external review at various junctures.

In order to avoid conflict through four phases of a project (permitting, injection, post-closure and stewardship), Wilson et al. (2008, p.2719) suggested that "the competing needs and interests of the public, project developers, financial and insurance institutions, government regulatory agencies, nongovernmental organizations and national and international agencies managing $\mathrm{CO}_{2}$ trading must be appropriately balanced". At the international level, risk assessment and risk management need to be comparable in an effort to ensure long-term reliability of storage sites and the assessment 
of CCS-based emissions reductions. This also relates to issues identified by Pawar et al. (2015) in their assessment of what needs to be done to improve overall risk management and to remove barriers associated with large-scale deployment. Essentials include stakeholder confidence in quantitative risk assessment approaches; testing the effectiveness of integrating risk assessment with monitoring and mitigation in risk management; and further development of outreach and effective communication strategies in order to minimise risks and boost acceptance of wide-scale deployment of GCS [storage] technology (Pawar et al., 2015).

The application of the IRMF within a risk-based decision making context would improve understanding and consensus of stakeholders for the principles of risk management, economic analysis, sociopolitical considerations and risk perception. Risk management options for CCS under five action categories would be identified, including regulatory, economic, advisory, community-based and technology based approaches. Indeed, coordinated action at multiple levels and multiple scales is considered best practice in a decision making context to protect or improve human health and the natural environment upon which we depend. Key risk management options include: regulations for baseline measurements, injection and storage operations, contaminant emissions and leakage rates, monitoring requirements and public reporting; penalties, fines and liability funds; notification processes; community-based siting and emergency response planning; training and operations strategies; and monitoring technologies, alarms and shut down procedures.

Carbon capture and storage may yet be implemented as the preferred option for industrial $\mathrm{CO}_{2}$ emissions stemming from the Canadian western oil and gas sector, coal fired electricity plants in Saskatchewan and Nova Scotia and the cement, steel, fertiliser and other trade exposed industries across the country. The implementation of a comprehensive, rational and integrated risk management framework that arrives at credible risk control options could engender public acceptance. Population and environmental health would be better protected in the vicinity of local projects at the same time as a growing number of CCS projects could contribute to global climate change mitigation, with anticipated health and environmental benefits worldwide.

Supplementary material is available online at Harvard Dataverse (https://dataverse.harvard.edu/)

\section{Acknowledgements}

This research was funded by Carbon Management Canada (CMC), a federally funded Network of Centres of Excellence. The authors also thank three anonymous reviewers.

\section{References}

Al Eidan, A., Bachu, S., Melzer, S., Lars, E.I. and Ackiewicz, M. (2015) Technical Challenges in the Conversion of $\mathrm{CO}_{2}-\mathrm{EOR}$ Projects to $\mathrm{CO}_{2}$ Storage Projects [online] https://www.onepetro.org/conference-paper/SPE-174575-MS (accessed 19 September 2018).

Alberta Energy (2018a) Alberta's CCS Knowledge Sharing Program [online] https://www.energy.alberta.ca/AU/CCS/KnowledgeSP/Pages/default.aspx (accessed 21 September 2018). 
Alberta Energy (2018b) Carbon Capture and Storage (CCS) Regulatory Framework Assessment [online] https://www.energy.alberta.ca/AU/CCS/Pages/LandP.aspx (accessed 18 August 2018).

Alberta Energy Regulator (2013) Alternative Dispute Resolution Program and Guidelines for Energy Industry Disputes [online] http://www.aer.ca/documents/manuals/Manual004.pdf (accessed 1 May 2018).

Alberta Energy Regulator (2018a) Directives [online] https://www.aer.ca/rules-and-regulations/ directives (accessed 1 May 2018).

Alberta Energy Regulator (2018b) Participant Involvement Initiative [online] https://www.aer.ca/ regulating-development/project-application/integrated-decision-approach/participantinvolvement (accessed 26 September 2018).

Alberta Energy Regulator (2019) Draft Directive XXX_Public Involvement [online] https://aer.ca/regulating-development/rules-and-directives/directives/directive-XXX-draft (accessed 5 July 2019).

Bachu, S. (2003) 'Screening and ranking of sedimentary basins for sequestration of $\mathrm{CO}_{2}$ in geological media in response to climate change', Environmental Geology, Vol. 44, No. 3, pp.277-289, DOI: 10.1007/s00254-003-0762-9.

Bankes, N. (2019) 'Alberta's approach to the transfer of liability for carbon capture and storage projects', International Journal of Risk Assessment and Management, in this issue.

Bankes, N. and Ference, T. (2009) ERCB Decision on an Acid Gas Disposal Scheme: Further Lessons for the Regulation of Carbon Capture and Storage Schemes - January 82009 [online] http://ablawg.ca/2010/01/08/ercb-decision-on-an-acid-gas-disposal-scheme-furtherlessons-for-the-regulation-of-carbon-capture-and-storage-schemes/ (accessed 1 May 2018).

BC Oil and Gas Commission (2017) About Us [online] https://www.bcogc.ca/about-us (accessed 1 May 2018).

Bowden, A.R. and Rigg, A. (2004) 'Assessing risk in $\mathrm{CO}_{2}$ storage projects', APPEA Journal 2004, pp.677-702.

Bowden, A.R., Pershke, D.F. and Chalaturnyk, R. (2013a) 'Biosphere risk assessment for $\mathrm{CO}_{2}$ storage projects', International Journal of Greenhouse Gas Control, Vol. 16, pp.S291-S308, DOI: 10.1016/j.ijggc.2013.02.015.

Bowden, A.R., Pershke, D.F. and Chalaturnyk, R. (2013b) 'Geosphere risk assessment conducted for the IEAGHG Weyburn-Midale $\mathrm{CO}_{2}$ Monitoring and storage project', International Journal of Greenhouse Gas Control, Vol. 16, pp.S276-S290, DOI: 10.1016/j.ijggc.2013.02.014.

British Columbia Ministry of Energy and Mines (2012) British Columbia's Natural Gas Strategy: Fuelling B.C.'s Economy for the Next Decade and Beyond [online] http://www.gov.bc.ca/ener/popt/down/natural_gas_strategy.pdf (accessed 19 September 2018).

Campbell-Arvai, V., Bessette, D., Kenney, L. and Arvai, J. (2019) 'Improving decision-making processes for carbon management initiatives', International Journal of Risk Assessment and Management, in this issue.

CCS Nova Scotia (2015) CCS Nova Scotia: Executive Summary [online] https://www.nspower.ca/site/media/Parent/CCSNS\%20Geological\%20Research\%20Executive\%20Summary\%20-April\%202015.pdf (accessed 11 September 2018).

Choptiany, J.M.H. and Pelot, R. (2014) 'A multicriteria decision analysis model and risk assessment framework for carbon capture and storage', Risk Anal, Vol. 34, No. 9, pp.1720-37, DOI: 10.1111/risa.12211.

Choptiany, J.M.H., Pelot, R., Brydie, J. and Gunter, W. (2015) 'An MCDA risk assessment framework for carbon capture and storage', International Journal of Decision Support Systems, Vol. 1, No. 4, pp.349-390. 
CMC Research Institutes and Pembina Institute (2019) CCUS: Priorities and Pathways Workshop_Summary Report of September 25, 2018 Workshop [online] https://cmcghg.com/priorities-and-pathways-ccus-workshop-summary-report/ (accessed 1 April 2019).

Commission on Social Determinants of Health (2008) Closing the Gap in a Generation: Health Equity through Action on the Social Determinants of Health [online] http://www.who.int/social_determinants/thecommission/finalreport/en/ (accessed 30 August 2018).

CSA Group (2012) CSA Z741:2012 Geological Storage of Carbon Dioxide [online] https://store.csagroup.org/ccrz_Products? cartID=\&operation=quickSearch\&searchText=filter codes and standards $\sim$ geological $\% 20$ storage \&searchFilter $=$ filter codes and standards\&is $\bar{C}$ SRFlow $=$ true\&portalUser $=\&$ store $=\& c c l c l=$ en US $($ accessed 7 September $20 \overline{18})$.

Det Norske Veritas (2010a) Independent Project Review (IPR) of Storage Component of the QUEST Carbon Capture and Storage Project [online] https://www.energy.alberta.ca/AU/ CCS/KnowledgeSP/Documents/2011/IndependentProjectReviewofStorageComponentofCCSP roject.pdf (accessed 20 September 2018).

Det Norske Veritas (2010b) Project Specific Guideline for Safe, Reliable and Cost-Effective Transmission of $\mathrm{CO}_{2}$ in Pipelines [online] http://rules.dnvgl.com/docs/pdf/DNV/codes/docs/ 2010-04/RP-J202.pdf (accessed 7 September 2018).

Det Norske Veritas (2010c) Qualification Procedures for $\mathrm{CO}_{2}$ Capture Technology [online] http://rules.dnvgl.com/docs/pdf/DNV/codes/docs/2010-04/RP-J201.pdf (accessed 23 July 2018).

Det Norske Veritas (2012) Geological Storage of Carbon Dioxide [online] https://www.dnvgl.com/ services/carbon-capture-utilisation-and-storage-ccus--5196 (accessed 23 July 2018).

Det Norske Veritas (2013) $\mathrm{CO}_{2} \mathrm{RISKMAN}$, Guidance on $\mathrm{CCS} \mathrm{CO}_{2}$ Safety and Environment, Major Accident Hazard Risk Management, Level 1, 2, 3 and 4 [online] https://www.dnvgl.com/ oilgas/joint-industry-projects/ongoing-jips/co2riskman.html (accessed 6 September 2018).

Dixon, T., McCoy, S.T. and Havercroft, I. (2015) 'Legal and regulatory developments on CCS', International Journal of Greenhouse Gas Control, Vol. 40, pp.431-448, DOI: 10.1016/j.ijggc.2015.05.024.

ecoEnergy Carbon Capture and Storage Task Force (2008) Canada's Fossil Energy Future: The Way Forward on Carbon Capture and Storage [online] http://www.nrcan.gc.ca/sites/ www.nrcan.gc.ca/files/www/pdf/com/resoress/publications/fosfos/fosfos-eng.pdf (accessed 20 September 2018).

Energy Resources Conservation Board (2012) Decision: Shell Canada Limited, Application for the Quest Carbon Capture and Storage Project, Radway Field [online] https://www.aer.ca/ documents/decisions/2012/2012-ABERCB-008.pdf (accessed 20 September 2018).

Environment Canada (2018) Reduction of Carbon Dioxide Emissions from Coal-Fired Generation of Electricity Regulations, SOR/2012-167 [online] http://ec.gc.ca/lcpe-cepa/eng/regulations/ detailReg.cfm?intReg=209; http://laws-lois.justice.gc.ca/eng/regulations/SOR-2012-167/index.html (accessed 20 September 2018).

European Union (2009) Directive 2009/31/EC on the Geological Storage of Carbon Dioxide and Amending other Directives [online] http://eur-lex.europa.eu/LexUriServ/LexUriServ.do? uri=OJ:L:2009:140:0114:0135:EN:PDF (accessed 4 August 2018).

Forbes, S.M., Almendra, F. and Ziegler, M.S. (2010) CCS and Community Engagement [online] http://pdf.wri.org/ccs_and_community_engagement.pdf (accessed 4 August 2018).

Fluker, S. (2009) The Problem of Locus Standi at the Energy Resources Conservation Board: A Diceyan Solution, 17 November [online] http://ablawg.ca/wp-content/uploads/2009/11/ blog sf kelly abca nov2009.pdf (accessed 01 May 2017). 
Gale, J., Abanades, J.C., Bachu, S. and Jenkins, C. (2015) 'Special issue commemorating the 10th year anniversary of the publication of the intergovernmental panel on climate change special report on $\mathrm{CO}_{2}$ capture and storage', International Journal of Greenhouse Gas Control, Vol. 40, pp.1-5, DOI: 10.1016/j.ijggc.2015.06.019.

GCCSI (2018) Status of CCS Project Database [online] https://www.globalccsinstitute.com/ projects/large-scale-ccs-projects (accessed 20 September 2018).

GCCSI (2019) openCCS Project Handbook [online] https://www.globalccsinstitute.com/ resources/publications-reports-research/?search=openCCS + Project + Handbook (accessed 23 July 2018).

Gerstenberger, M.C., Christophersen, A., Buxton, R., Allinson, G., Hou, W., Leamon, G. and Nicol, A. (2013) 'Integrated risk assessment for CCS', Energy Procedia, Vol. 37, pp.2775-2782, DOI: 10.1016/j.egypro.2013.06.162.

Godec, M.L., Riestenberg, D. and Cyphers, S. (2017) 'Potential issues and costs associated with verifying $\mathrm{CO}_{2}$ storage during and after $\mathrm{CO}_{2}$-EOR', Energy Procedia, Vol. 114, pp.7399-7414, DOI: 10.1016/j.egypro.2017.03.1870.

Government of Alberta (2015) Climate Leadership Plan will Protect Albertans' Health, Environment and Economy [online] http://www.alberta.ca/climate-leadership-plan.aspx (accessed 8 August 2018).

Government of Alberta (2018) Carbon Levy and Rebates [online] https://www.alberta.ca/climatecarbon-pricing.aspx\#p184s1 (accessed 19 September 2018).

Government of British Columbia (2008a) Climate Action Plan [online] https://www2.gov.bc.ca/assets/gov/environment/climate-change/action/cap/climateaction plan_web.pdf (accessed 20 September 2018).

Government of British Columbia (2008b) Oil and Gas Activities Act, [SBC2008] Chapter 36 [online] http://www.bclaws.ca/civix/document/id/complete/statreg/08036_01 (accessed 20 September 2018).

Government of British Columbia (2012) Petroleum and Natural Gas Act, [RSBC 1996] Chapter 361 [online] http://www.bclaws.ca/EPLibraries/bclaws_new/document/ID/freeside/00_96361 01\#part5_division3 (accessed 1 May 2018).

Government of British Columbia (2014) Climate Action in British Columbia: 2014 Progress Report [online] http://www2.gov.bc.ca/assets/gov/environment/climate-change/action/ progress-to-targets/2014-progress-to-targets.pdf (accessed 20 September 2018).

Government of British Columbia (2016) Carbon Capture and Storage Regulatory Policy Framework [online] http://www2.gov.bc.ca/gov/content/industry/natural-gas-oil/responsibleoil-gas-development/carbon-capture-storage/ccs-reg-framework (accessed 20 September 2018).

Government of British Columbia (2017a) Environmental Assessment Act, [SBC 2002] Chapter 43 [online] http://www.bclaws.ca/Recon/document/ID/freeside/00_02043_01 (accessed 20 September 2018).

Government of British Columbia (2017b) Environmental Management Act, [SBC 2003] Chapter 53 [online] http://www.bclaws.ca/Recon/document/ID/freeside/03053_00 (accessed 21 June 2018).

Government of British Columbia (2017c) Oil and Gas Activities Act Drilling and Production Regulation, 282/2010 [online] http://www.bclaws.ca/civix/document/id/loo97/loo97/282_2010 (accessed 20 September 2018).

Government of British Columbia (2017d) Waste Discharge Authorizations [online] http://www2.gov.bc.ca/gov/content/environment/waste-management/waste-dischargeauthorization (accessed 20 September 2018).

Government of Canada (2011) Oil Sands, A Strategic Resource for Canada, North America and the Global Market [online] http://publications.gc.ca/collections/collection_2011/rncan-nrcan/ M164-4-4-1-2011-eng.pdf (accessed 8 August 2018). 
Government of Canada (2012a) Canadian Environmental Assessment Act [online] http://lawslois.justice.gc.ca/eng/acts/C-15.21/ (accessed 20 September 2018).

Government of Canada (2012b) Canadian Environmental Assessment Act, Repealed, c.19, s.66 [online] http://laws-lois.justice.gc.ca/eng/acts/C-15.2/ (accessed 20 September 2018).

Government of Canada (2016a) Canada's Action on Climate Change, no longer available (accessed 28 January 2016).

Government of Canada (2016b) Canada's Second Biennial Report on Climate Change [online] $\mathrm{http} / /$ unfccc.int/files/national_reports/biennial_reports and iar/submitted biennial_reports/ap plication/pdf/canadas_2nd_biennial_report.pdf (accessed 6 September 2018).

Government of Canada (2016c) The Government of Canada Accelerates Investments in Clean Electricity [online] https://www.canada.ca/en/environment-climate-change/news/2016/11/ government-canada-accelerates-investments-clean-electricity.html (accessed 20 September 2018).

Government of Canada (2016d) The Pan-Canadian Framework on Clean Growth and Climate Change [online] https:/www.canada.ca/content/dam/themes/environment/documents/ weather1/20170125-en.pdf (accessed 10 October 2018).

Government of Canada (2018a) Bill C-69, An Act to enact the Impact Assessment Act and the Canadian Energy Regulator Act, to amend the Navigation Protection Act and to make Consequential Amendments to other Acts [online] http://www.parl.ca/DocumentViewer/en/421/bill/C-69/third-reading (accessed 30 November 2018).

Government of Canada (2018b) Regulations Limiting Carbon Dioxide Emissions from Natural Gas-fired Generation of Electricity [online] http://gazette.gc.ca/rp-pr/p1/2018/2018-0217/html/reg4-eng.html (accessed 17 September 2018).

Government of Canada (2019) An Act to enact the Impact Assessment Act and the Canadian Energy Regulator Act, to Amend the Navigation Protection Act and to Make Consequential Amendments to other Acts [online] https:/www.parl.ca/Content/Bills/421/Government/C69/C-69_4/C-69_4.PDF (accessed 5 July 2019).

Government of Saskatchewan (2011) The Pipelines Act, Chapter P-12.1* of the Statutes of Saskatchewan, 1998 (effective April 1, 2000) as amended [online] http://www.publications.gov.sk.ca/details.cfm?p=754 (accessed 20 September 2018).

Government of Saskatchewan (2014a) Environmental Assessment in Saskatchewan [online] http://publications.gov.sk.ca/documents/66/89131EnvironmentalAssessmentProcessGuidelines.pdf (accessed 20 September 2018).

Government of Saskatchewan (2014b) The Oil and Gas Conservation Act, Chapter 0-2, as amended [online] http://www.qp.gov.sk.ca/documents/English/Statutes/Statutes/O2.pdf (accessed 20 September 2018).

Government of Saskatchewan (2018) The Environmental Assessment Act, Chapter E-10.1 of the Statutes of Saskatchewan 1979-80 (Effective August 25, 1980) as Amended [online] http://www.qp.gov.sk.ca/documents/English/Statutes/Statutes/E10-1.pdf (accessed 26 June 2019).

Heyes, J.A. and Urban, I.B. (2019) 'The economic evaluation of the benefits and costs of carbon capture and storage', International Journal of Risk Assessment and Management, in this issue.

Hnottavange-Telleen, K., Chabora, E., Finley, R.J., Greenberg, S.E. and Marsteller, S. (2011) 'Risk management in a large-scale $\mathrm{CO}_{2}$ geosequestration pilot project, Illinois, USA', Energy Procedia, Vol. 4, pp.4044-4051, DOI: 10.1016/j.egypro.2011.02.346.

IEA (2014) Carbon Capture and Storage: Legal and Regulatory Review [online] https://www.iea.org/publications/insights/insightpublications/CCSReview_4thEd_FINAL.pdf (accessed 10 May 2018).

IEA (2015a) Carbon Capture and Storage: The Solution for Deep Emissions Reductions [online] https://www.iea.org/publications/freepublications/publication/carbon-capture-and-storagethesolution-for-deep-emissions-reductions.html (accessed 16 August 2018). 
IEA (2015b) Storing $\mathrm{CO}_{2}$ through Enhanced Oil Recovery [online] https://www.iea.org/ publications/insights/insightpublications/storing-co2-through-enhanced-oil-recovery.html (accessed 8 September 2018).

IEA (2016) 20 Years of Carbon Capture and Storage [online] https://www.iea.org/publications/ freepublications/publication/20YearsofCarbonCaptureandStorage_WEB.pdf (accessed 20 August 2018).

IEA (2018) Industrial applications of CCS [online] https://www.iea.org/topics/ccs/ industrialapplicationsofccs/ (accessed 6 September 2018).

International Energy Agency Greenhouse Gas R\&D Programme (IEAGHG) (2010) The Regulatory Framework Governing Injection and Storage of Carbon Dioxide at the Cenovus Weyburn and Apache Midale Enhanced Oil Recovery Operations in Saskatchewan [online] http://ccs101.ca/assets/Documents/The\%20Regulatory\%20Framework\%20Governing\%20Inje ction $\% 20$ and $\% 20$ Storage $\% 20$ of $\% 20$ Carbon $\% 20$ Dioxide $\% 20 \% 20$ in $\% 20$ SaskatchewanApril $\%$ 206\%202010.pdf (accessed 20 September 2018).

International Energy Agency Greenhouse Gas R\&D Programme (IEAGHG) (2016) Review of GHG Accounting Rules for CCS, Report 2016/TR3 [online] https://ieaghg.org/docs/ General_Docs/Reports/2016-TR3.pdf (accessed 17 September 2018).

International Energy Agency Greenhouse Gas R\&D Programme (IEAGHG) (2017) CCS Deployment in the Context of Regional Developments in Meeting Long-Term Climate Change Objectives, Technical Report 2017-07 [online] https://ieaghg.org/exco_docs/2017-07.pdf (accessed 17 September 2018).

IPCC (2005) IPCC Special Report on Carbon Dioxide Capture and Storage [online] http://www.ipcc.ch/pdf/special-reports/srccs/srccs_wholereport.pdf (accessed 16 August 2018).

Jardine, C., Hrudey, S., Shortreed, J., Craig, L., Krewski, D., Furgal, C. and McColl, S. (2003) 'Risk management frameworks for human health and environmental risks', J Toxicol Environ Health B Crit Rev, Vol. 6, No. 6, pp.569-720, DOI: 10.1080/10937400390208608.

Jenkins, C., Chadwick, A. and Hovorka, S.D. (2015) 'The state of the art in monitoring and verification - ten years on', International Journal of Greenhouse Gas Control, Vol. 40, pp.312-349, DOI: 10.1016/j.ijggc.2015.05.009.

Keith, D.W., Giardina, J.A., Morgan, M.G. and Wilson, E.J. (2005) 'Regulating the underground injection of $\mathrm{CO}_{2}$, Environmental Science and Technology, 15 December, Vol. 39, pp.499A-505A.

Kern, F., Gaede, J., Meadowcroft, J. and Watson, J. (2016) 'The political economy of carbon capture and storage: an analysis of two demonstration projects', Technological Forecasting and Social Change, Vol. 102, pp.250-260, DOI: 10.1016/j.techfore.2015.09.010.

Koornneef, J., Ramirez, A., Turkenburg, W. and Faaij, A. (2012) 'The environmental impact and risk assessment of $\mathrm{CO}_{2}$ capture, transport and storage - an evaluation of the knowledge base', Progress in Energy and Combustion Science, Vol. 38, pp.62-86, DOI: 10.1016/j.pecs.2011.05.002.

Krewski, D., Hogan, V., Turner, M.C., Zeman, P.L., McDowell, I., Edwards, N. and Losos, J. (2007) 'An integrated framework for risk management and population health', Human and Ecological Risk Assessment: An International Journal, Vol. 13, No. 6, pp.1288-1312, DOI: $10.1080 / 10807030701655798$.

Krewski, D., Turner, M.C., Lemyre, L. and Lee, J.E.C. (2012) 'Expert vs. public perception of population health risks in Canada', Journal of Risk Research, Vol. 15, No. 6, pp.601-625, DOI: $10.1080 / 13669877.2011 .649297$.

Krewski, D., Westphal, M., Andersen, M.E., Paoli, G.M., Chiu, W.A., Al-Zoughool, M., Croteau, M.C., Burgoon, L.D. and Cote, I. (2014) 'A framework for the next generation of risk science', Environ Health Perspect, Vol. 122, No. 8, pp.796-805, DOI: 10.1289/ehp.1307260. 
Krupa, H.J. (2011) 'The legal framework for carbon capture and storage in Canada', in Havercroft, I., MacRory, R. and Stewart, R. (Eds.): Carbon Capture and Storage: Emerging Legal and Regulatory Issues, pp.39-66, Hart Publishing, London, DOI: 10.5040/9781472565693.ch-003.

L'Orange Seigo, S., Arvai, J., Dohle, S. and Siegrist, M. (2014a) 'Predictors of risk and benefit perception of carbon capture and storage (CCS) in regions with different stages of deployment', International Journal of Greenhouse Gas Control, Vol. 25, pp.23-32, DOI: 10.1016/j.ijggc.2014.03.007.

L'Orange Seigo, S., Dohle, S. and Siegrist, M. (2014b) 'Public perception of carbon capture and storage (CCS): a review', Renewable and Sustainable Energy Reviews, Vol. 38, pp.848-863, DOI: 10.1016/j.rser.2014.07.017.

Larkin, P. (2017) An Integrated Risk Management Framework for Carbon Capture and Storage in the Canadian Context, PhD Thesis [online] http://hdl.handle.net/10393/35881 (accessed 20 September 2018).

Larkin, P., Dusseault, M., Gracie, R.G., Sarkarfarshi, A.M., Shafiei, A., Aspinall, W. and Krewski, D. (2019a) 'Risk management in carbon capture and storage: insights from a structured expert elicitation', International Journal of Risk Assessment and Management, in this issue.

Larkin, P., Dusseault, M., Gracie, R.G., Sarkarfarshi, A.M., Shafiei, A., Aspinall, W. and Krewski, D. (2019b) 'Uncertainty in risk issues for carbon capture and storage: findings from a structured expert elicitation', International Journal of Risk Assessment and Management, in this issue.

Larkin, P., Leiss, W. and Krewski, D. (2019c) 'The evolution of regulatory practice for CCS projects in Canada', International Journal of Risk Assessment and Management, in this issue.

Larkin, P., Leiss, W. and Krewski, D. (2019d) 'Risk assessment and management frameworks for carbon capture and storage: a global perspective', International Journal of Risk Assessment and Management, in this issue.

Leiss, W. (2009) Risk Management of Carbon Capture and Storage: Overview and Future Steps [online] http://leiss.ca/wp-content/uploads/2009/12/LeissCCS-RM2009.pdf (accessed 20 September 2018).

Leiss, W. and Krewski, D. (2019) 'Environmental scan and issue awareness: risk management challenges for CCS', International Journal of Risk Assessment and Management, in this issue.

Leiss, W. and Larkin, P. (2019) 'Risk communication and public engagement in CCS projects: the foundations of public acceptability', International Journal of Risk Assessment and Management, in this issue.

Leiss, W., Tyshenko, M.G., Krewski, D., Cashman, N., Lemyre, L. and Al-Zoughool, M. (2010) 'Managing the risks of bovine spongiform encephalopathy: a Canadian perspective', International Journal of Risk Assessment and Management, Vol. 14, No. 5, pp.381-436.

Mabon, L. and Littlecott, C. (2016) 'Stakeholder and public perceptions of $\mathrm{CO}_{2}$-EOR in the context of CCS - results from UK focus groups and implications for policy', International Journal of Greenhouse Gas Control, Vol. 49, pp.128-137, DOI: 10.1016/j.ijggc.2016.02.031.

MIT (2018) Carbon Capture \& Sequestration Project Database [online] http://sequestration.mit.edu/tools/projects/index.html (accessed 19 August 2018).

National Energy Technology Laboratory (2013) Carbon Storage Systems and Well Management Activities [online] https:/www.netl.doe.gov/research/coal/carbon-storage/strategic-programsupport/best-practices (accessed 4 August 2018).

National Energy Technology Laboratory (2017a) Best Practices: Monitoring, Verification, and Accounting (MVA) of Geologic Storage Projects [online] https://www.netl.doe.gov/ File\%20Library/Research/Carbon-Storage/Project-Portfolio/BPM-MVA-2012.pdf (accessed 7 September 2018). 
National Energy Technology Laboratory (2017b) Best Practices: Public Outreach and Education for Geologic Storage Projects [online] https://www.netl.doe.gov/File\%20Library/Research/ Carbon-Storage/Project-Portfolio/BPM_PublicOutreach.pdf (accessed 7 September 2018).

National Energy Technology Laboratory (2017c) Best Practices: Risk Management and Simulation for Geologic Storage Projects [online] https://www.netl.doe.gov/File\%20Library/Research/ Carbon-Storage/Project-Portfolio/BPM_RiskAnalysisSimulation.pdf (accessed 7 September 2018).

National Energy Technology Laboratory (2017d) Best Practices: Site Screening, Site Selection, and Site Characterization for Geologic Storage Projects [online] https://www.netl.doe.gov/ File\%20Library/Research/Carbon-Storage/Project-Portfolio/BPM-SiteScreening.pdf (accessed 7 September 2018).

National Research Council (1983) Risk Assessment in the Federal Government: Managing the Process [online] www.nap.edu/catalog/366.html (accessed 16 August 2018).

National Research Council (2009) Science and Decisions: Advancing Risk Assessment [online] https://www.ncbi.nlm.nih.gov/pubmed/25009905 (accessed 14 August 2018).

Natural Resources Canada (2006) Canada's $\mathrm{CO}_{2}$ Capture and Storage Technology Roadmap [online] http://publications.gc.ca/collections/collection_2014/rncan-nrcan/M154-162008-eng.pdf (accessed 20 September 2018).

Natural Resources Canada. (2019) Funding, Grants and Incentives [online] https://www.nrcan.gc.ca/cleangrowth/20254 (accessed 3 April 2019).

North American Carbon Atlas Partnership (2012) North American Carbon Storage Atlas, First Edition [online] http://www.netl.doe.gov/File\%20Library/Research/Coal/carbon-storage/ global\%20collab/NACSA2012.pdf (accessed 30 August 2018).

Nova Scotia Government (2009) Toward a Greener Future - Nova Scotia's Climate Change Action Plan [online] https://climatechange.novascotia.ca/sites/default/files/uploads/ccap.pdf (accessed 19 September 2018).

Pawar, R.J., Bromhal, G.S., Carey, J.W., Foxall, W., Korre, A., Ringrose, P.S., Tucker, O., Watson, M.N. and White, J.A. (2015) 'Recent advances in risk assessment and risk management of geologic $\mathrm{CO}_{2}$ storage', International Journal of Greenhouse Gas Control, Vol. 40, pp.292-311, DOI: 10.1016/j.ijggc.2015.06.014.

Polson, D., Curtis, A. and Vivalda, C. (2012) 'The evolving perception of risk during reservoir evaluation projects for geological storage of $\mathrm{CO}_{2}$ ', International Journal of Greenhouse Gas Control, Vol. 9, pp.10-23, DOI: 10.1016/j.ijggc.2012.02.010.

Province of Alberta (2010a) Carbon Capture and Storage Statutes Amendment Act [online] http://www.assembly.ab.ca/ISYS/LADDAR_files/docs/bills/bill/legislature_27/session_3/201 00204_bill-024.pdf (accessed 20 September 2018).

Province of Alberta (2010b) Environmental Protection and Enhancement Act, Revised Statutes of Alberta 2000, Chapter E-12, current as of 15 March 2017 [online] http://www.qp.alberta.ca/ documents/acts/e12.pdf (accessed 9 April 2018).

Province of Alberta (2011) Carbon Sequestration Tenure Regulation, O.C. 179/2011, A.R. 68/2011, 28 April [online] http://www.qp.alberta.ca/documents/orders/orders in council/ 2011/411/2011_179.html (accessed 1 May 2018).

Province of Alberta (2013a) Mines and Minerals Act [online] http://www.qp.alberta.ca/ documents/acts/m17.pdf (accessed 20 September 2018).

Province of Alberta (2013b) Oil Sands Conservation Act, Revised Statutes of Alberta 2000, Chapter O-7 [online] http://www.qp.alberta.ca/documents/Acts/O07.pdf (accessed 20 September 2018).

Province of Alberta (2014) Water Act, Revised Statues of Alberta 2000, Chapter W-3 [online] http://www.qp.alberta.ca/1266.cfm?page=w03.cfm\&leg_type=Acts\&isbncln=9780779733651 (accessed 20 September 2018). 
Province of Alberta (2017) Oil and Gas Conservation Act, Revised Statutes of Alberta 2000, Chapter O-6 [online] http://www.qp.alberta.ca/documents/Acts/O06.pdf (accessed 20 September 2018).

Province of British Columbia (2014a) Carbon Capture and Storage Regulatory Policy, Consultation Summary Report [online] http://www2.gov.bc.ca/assets/gov/farming-naturalresources-and-industry/natural-gas-oil/ccs/ccs_consultation_summary_report.pdf (accessed 20 September 2018).

Province of British Columbia (2014b) Carbon Capture and Storage Regulatory Policy, Discussion and Comment Paper [online] http://www2.gov.bc.ca/gov/content/industry/natural-gasoil/responsible-oil-gas-development/carbon-capture-storage/ccs-reg-framework (accessed 20 September 2018).

Province of Nova Scotia (2012) Environmental Goals and Sustainable Prosperity Act, Chapter 7 of the Acts of 2007 , as amended by 2012 , c. 42 [online] http://nslegislature.ca/legc/statutes/ environmental $\% 20$ goals $\% 20$ and $\% 20$ sustainable $\% 20$ prosperity.pdf (accessed 20 September 2018).

Salomons, G.H. and Hoberg, G. (2014) 'Setting boundaries of participation in environmental impact assessment', Environmental Impact Assessment Review, Vol. 45, pp.69-75, DOI: 10.1016/j.eiar.2013.11.001.

Sarkarfarshi, A., Ladubec, C., Gracie, R.G., Dusseault, M., Leiss, W. and Krewski, D. (2019) 'Potential technical hazards associated with four north american carbon capture and sequestration projects', International Journal of Risk Assessment and Management, in this issue.

Smith, M., Campbell, D., Mackay, E. and Polson, D. (2011) $\mathrm{CO}_{2}$ Aquifer Storage Site Evaluation and Monitoring [online] http://carbcap.geos.ed.ac.uk/website/publications/cassem/ CASSEM_Comp-12_12_11.pdf (accessed 20 September 2018).

Specific Mitigation Opportunities Working Group (2016) Final Report, Government of Canada, Ottawa, ON [online] https:/www.canada.ca/content/dam/eccc/migration/cc/content $/ 6 / 4 / 7 /$ 64778dd5-e2d9-4930-be59-d6db7db5cbc0/wg_report_specific_mitigation_opportunities_ en_v04.pdf (accessed 20 September 2018).

Supreme Court of Canada (2014) Canada Supreme Court Reports, 2 S.C.R. 3-322 [online] https://scc-csc.lexum.com/scc-csc/scc-csc/en/14246/1/document.do (accessed 20 September 2018).

United Nations Framework Convention on Climate Change (2011) Modalities and Procedures for Carbon Dioxide Capture and Storage in Geological Formations as Clean Development Mechanism Project Activities [online] http://unfccc.int/resource/docs/2011/cmp7/eng/ 10a02.pdf\#page $=13$ (accessed 23 August 2018).

United Nations Framework Convention on Climate Change (2015) Adoption of the Paris Agreement FCCC/CP/2015/L.9 [online] http:/unfccc.int/resource/docs/2015/cop21/eng/ 109.pdf (accessed 16 August 2018).

US Department of Energy (2007) Final Risk Assessment Report for the FutureGen Project Environmental Impact Statement [online] http://energy.gov/sites/prod/files/EIS-0394-DEISRiskAssessmentReport-2007.pdf (accessed 20 September 2018).

US Environmental Protection Agency (2011) Underground Injection Control (UIC) Program: Federal Requirements for Class VI Injection Wells for the Geologic Sequestration of Carbon Dioxide [online] http://www.regulations.gov/document?D=EPA-HQ-OW-2008-0390-0395 (accessed 4 August 2018).

Wilson, E.J., Johnson, T.L. and Keith, D.W. (2003) 'Regulating the ultimate sink: managing the risks of geologic $\mathrm{CO}_{2}$ storage', Environmental Science and Technology, Vol. 37, No. 16, pp.3476-3483, DOI: $10.1021 / \mathrm{es} 021038$. 
Wilson, E.J., Morgan, M.G., Apt, J., Bonner, M., Bunting, C., Gode, J., Haszeldine, R.S., Jaeger, C.C., Keith, D.W., McCoy, S.T., Pollak, M.F., Reiner, D.M., Rubin, E.S., Torvanger, A., Ulardic, C., Vajjhala, S.P., Victor, D.G. and Wright, I.W. (2008) 'Regulating the geological sequestration of $\mathrm{CO}_{2}$ ', Environmental Science and Technology, Vol. 42, No. 8, pp. $2718-2722$.

Wong, R., Goehner, A. and McCulloch, M. (2013) Net Greenhouse Gas Impact of Storing $\mathrm{CO}_{2}$ through Enhanced Oil Recovery (EOR), An analysis of on-site and downstream GHG emissions from $\mathrm{CO}_{2}$-EOR crude oil production in Western Canada [online] http://www.pembina.org/reports/ico2n-eor-full-report.pdf (accessed 20 September 2018).

World Resources Institute (2008) CCS Guidelines for Carbon Dioxide Capture, Transport, and Storage, Forbes, S.M., Verma, P., Curry, T.E., Friedmann, S.J. and Wade, S.M. (Eds.), WRI, Washington [online] http://pdf.wri.org/ccs_guidelines.pdf (accessed 4 August 2018).

\section{Notes}

1 At the time of publication, multiple attempts to ascertain the status of the project had been unsuccessful.

2 While undefined in CEAA2012, the Canadian Environmental Protection Act, 1999, suggests in "implementing the precautionary principle that, where there are threats of serious or irreversible damage, lack of full scientific certainty shall not be used as a reason for postponing cost-effective measures to prevent environmental degradation" (https://www.ec.gc.ca/lcpe-cepa/26A03BFA-C67E-4322-AFCA-2C40015E741C/lcpecepa_201310125_loi-bill.pdf). 